\title{
Mitigation of Uranium Mining Impacts-A Review on Groundwater Remediation Technologies
}

\author{
Maria de Lurdes Dinis *(D) and António Fiúza (D) \\ CERENA-Polo FEUP-Centre for Natural Resources and the Environment, Faculty of Engineering, \\ Porto University, 4200-465 Porto, Portugal; afiuza@fe.up.pt \\ * Correspondence: mldinis@fe.up.pt
}

\begin{abstract}
Groundwater contamination is one of the most concerning issues from uranium mining activities. Radionuclides cannot be destroyed or degraded, unlike some organic contaminants (and similar to metals). Besides, sites, where radionuclides may be found, are mainly radioactive and mixed waste disposal areas, and therefore many other contaminants may also be present in groundwater. The state-of-the-art of environmental technology is continually changing, and thus a review on technologies application is of utmost relevance. This work gives an overview of the available remediation technologies for groundwater contaminated with radionuclides resulting mainly from uranium mining. For each technology, a theoretical background is provided; the state of development, limitations, efficiency, and potential adverse effects are also approached. Examples of application and performance monitoring of remediation progress are described, and criteria for the selection of the appropriate remediation technology are given. The most effective remediation technology will always be site-specific as a result of the multitude of geographic and operational factors that influence the effluent quality and impact the technical feasibility of treatment methods. Ion exchange, chemical precipitation, and membrane filtration have been considered by the U.S. Environmental Protection Agency (US EPA) as best demonstrated available technologies for radium and uranium removal. Several factors have been demonstrated to influence the selection of a remediation technology (technological aspects and non-technical factors), but even for the technologies demonstrated or industrial proven, two important challenges remain; the (still) mobile radionuclides and the generation of secondary wastes. Besides, remediation technologies are constantly evolving, but future advancement depends on rigorously monitored, documented efficiency, and results achieved. Therefore, the technologies approached in this paper are by no means exhaustive.
\end{abstract}

Teresa Albuquerque, Rita Fonseca and Jesus Martinez-Frias

Received: 24 April 2021

Accepted: 3 June 2021

Published: 8 June 2021

Publisher's Note: MDPI stays neutral with regard to jurisdictional claims in published maps and institutional affiliations.

Keywords: groundwater; radionuclides; remediation; technologies uranium; uranium mining impact; water contamination

\section{Introduction}

Historically, mine sites have been a significant source of contamination to the environment, particularly in sites where the mining activity has ceased without an existing closure plan or a rehabilitation project. Such practices are no longer acceptable. Upon closure, decommissioning and environmental remediation of the site must take place, and in most cases, long-term monitoring to ensure the long-time stability of the site. Closure and decommissioning plans are mandatory at the initial design stage of the project.

Uranium mining can impact groundwater in several ways, mainly from the exploration, mining, processing, and waste management phases of the project. The contamination can occur from the ground surface (by infiltration of contaminated surface water, waste piles, tailings facilities, airborne particles, etc.), from above the water table (leaks in pipelines, leachates, etc.), or from below the water table (drainage wells, groundwater withdrawal, etc.) [1-3]. When considering impacts associated with uranium in water, it is essential to note that the risk of chemical toxicity can be much more significant than the radiological risk for a given uranium concentration. 
Different in-situ and ex-situ remediation options exist for contaminated groundwater: containment of the contaminants to prevent migration (e.g., using geotechnical measures), removal of the contamination source (e.g., by excavation and subsequent soil washing), groundwater treatment at the point of use, removal of the groundwater for treatment and replacement, or remediation of the groundwater in situ (e.g., the in-situ transformation of the contaminants to reduce their mobility and the toxicity). Many of these options are put in operation through the pump-and-treat systems, in situ permeable treatment wall system, monitored natural attenuation, enhanced attenuation technologies, and biological processes.

All these mechanisms have their advantages and limitations. Moreover, they are contaminant specific and strongly dependent on the subsurface environmental conditions of the site, which may constrain the entire remediation of the site or the application of some technologies which may be too costly to implement on a large scale or inadequate to address the magnitude and combinations of contamination problems. Besides, multiple technologies may be involved simultaneously at a particular site and change over time. Therefore, it is recognized that there is no single technology or a single combination of technologies that would apply to all contaminants under all subsurface environmental conditions.

On the other hand, sites, where radionuclides may be found, are mainly radioactive and mixed waste disposal areas, and therefore many other contaminants may also be present in groundwater. In all situations, designing and implementing effective prevention measures to avoid contamination are preferred over-relying on groundwater remediation after contamination has occurred. The groundwater clean-up systems which are widely used are expensive and need to be applied in practice for a long time, although, in recent years, remediation research has been focused on the development of new clean-up systems and improvement of the efficiency of the existing ones.

Remediation of groundwater impacted with dissolved metals, metalloids, and radionuclides is perhaps one of the biggest challenges for in situ environmental remediation today. Remedial strategies for the treatment of metals in groundwater generally involve direct precipitation or sorption/coprecipitation, with the goal of permanently sequestering and immobilizing the metals in the aquifer soil matrix. The success of this process is dependent upon many factors, such as the kinetics of the reaction, the equilibrium solubility (the solubility of the precipitated solid phases as they form), and durability/permanence (longterm stability of the precipitated solids) [4]. The result is a reduction in the groundwater radionuclide and metals concentrations, but these remain in situ.

This work gives an overview of the available remediation technologies for groundwater contaminated with radionuclides resulting mainly from uranium mining activities. For each technology, a theoretical background is provided. The state of development, applicability limitations, remediation efficiency, and potential adverse effects of these technologies are also approached. Examples of application and performance monitoring of remediation progress are described, and general criteria for selecting the appropriate remediation technology are given. For some of the presented case studies, the uranium concentration reported in groundwater samples ranged between $138 \mu \mathrm{g} / \mathrm{L}$ and $300 \mathrm{mg} / \mathrm{L}$. Additionally, when there are no such examples for the radionuclides related to uranium mining and milling activities, others are presented.

\section{Remediation Technologies}

Remediation technologies can be grouped into three broad categories: physical, chemical, and biological methods (plant and microorganism methods). Each method has limitations and strengths, but the applicable remediation approach should be determined by the site-specific conditions. 
Several chemical, physical, biological, and combined methods have been developed to remediate groundwater contaminated with radionuclides originating from uranium mining activities. The available technologies include vertical barriers (U, Ra, Th, Rn), phytoremediation $(\mathrm{U})$, ion exchange $(\mathrm{U}, \mathrm{Ra})$, chemical precipitation $(\mathrm{U}, \mathrm{Ra})$, permeable reactive barrier $(\mathrm{U}, \mathrm{Ra})$, membrane process $(\mathrm{U}, \mathrm{Ra}, \mathrm{Th}, \mathrm{Rn})$, adsorption $(\mathrm{U}, \mathrm{Ra})$ and, monitored natural attenuation $(\mathrm{U}, \mathrm{Ra})$ [5-32].

The most straightforward approach seems to be the well-established methods of wastewater treatment. With the 'pump-and-treat' systems, the contaminated groundwater is removed from the ground by pumping and treated in a treatment plant on the surface. The approach relies on proven treatment techniques, is simple to manage, and the treated groundwater can be re-injected into the subsurface or discharged into surface water sources. However, this process has two main disadvantages: it disturbs the groundwater flow regime and requires steady energy and other inputs.

In the literature, there are references to other technologies that have been bench- or pilot-tested, with successful performance, such as those based on photo-induced technology (e.g., photocatalysis) [33], electro-remediation (e.g., electro-coagulation) [34,35], electrodialysis, and electrodialysis reversal (these systems are generally considered economically viable only for very small installations) [36]. Still, in what concerns full-scale demonstration, the information is scarce.

\subsection{Chemical Separation}

Chemical separation technologies for liquid media consist of separating and concentrating the contaminants from groundwater. The process generates residuals such as filters, filter cakes, carbon units, and ion exchange resins requiring further treatment, storage, or disposal. According to the types and concentrations of the contaminants, the extractability rates of the different chemical separation technologies may vary considerably. Still, site-conditions and characteristics will determine the applicability of chemical separation technologies when considering a specific site. Another issue remains from the ex-situ chemical separation technologies (ion exchange and chemical precipitation) in which a groundwater extraction and delivery system are required. These technologies will generate a treated effluent and a contaminated residual that requires further treatment or disposal.

\subsubsection{Ion-Exchange}

This technology has been successfully used in reducing radionuclide and inorganic metal concentrations in water bodies to levels suitable for effluent discharge. In a simplistic way, this technology separates and replaces radionuclides in a waste stream with ions from a synthetic resin or natural zeolite. The process can remove up to $99 \%$ of the contaminants (beta and alpha emitters, radium, and uranium) suspended in water by passing the water through cation (positively) or anion (negatively) charged resin media that binds the contaminants [13] (Figure 1).

Exchange resins for radium often use sodium and potassium, removing hardness elements such as iron, calcium, magnesium, and manganese. Resins have an insoluble structure with numerous ion transfer sites and an affinity for specific types of ions. When the exchangeable ions are bound to the resin with a weaker ionic bond than the one of the ion to be recovered (contaminant), the exchange ion goes into the solution, and the ionic contaminant binds to the resin. Resins must be regenerated regularly by exposing them to a concentrated solution of the original exchange ion. When zeolites are depleted, they are disposed of as solid waste. Resins are more expensive than other adsorption reagents, such as carbon, but they have higher selectivity than activated carbon [37]. 


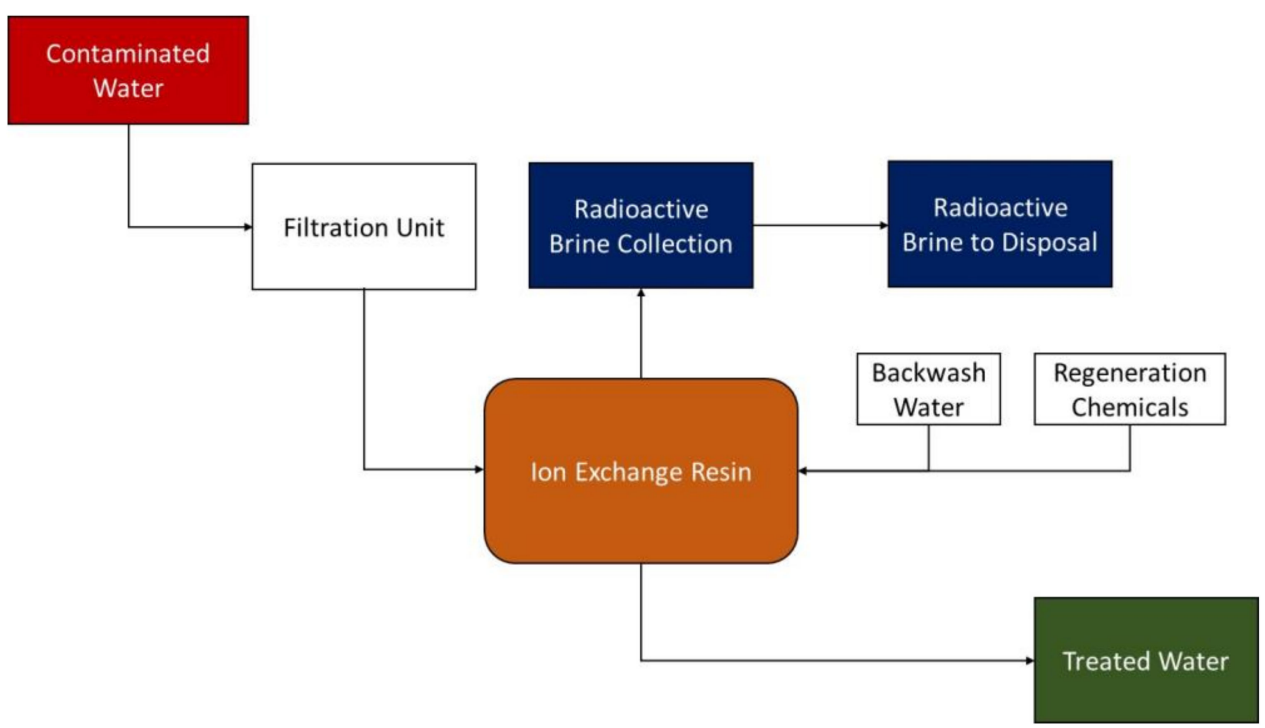

Figure 1. The general process involved in ion exchange [13].

Ion exchange technology immobilizes the contaminant in the exchange media but does not affect the radiotoxicity of the contaminant itself and, therefore, the concentrated waste removed from the resin and the spent resin must be treated, stored, or disposed of. Several factors can limit the effectiveness of this technology [13]:

- The cation-exchange capacity (CEC) of the resin media may be affected by the hardness ions which compete with radium ions;

- Clogging of the resin media due to high levels of Mg and Fe in source waters;

- Pretreatment of anionic waste streams or waste streams with suspended solids must be considered.

- $\mathrm{pH}$, temperature, concentration, flow rate, selectivity of the resin, and exchange capacity;

- If more than one radioactive contaminant is present, more than one resin or treatment process may be required.

The recovery of uranium from groundwater waste streams depends strongly on the type of uranium species in the solution. The higher the ion charge of the molecule, the more selective the resin will be towards the species (e.g., the uranyl carbonate complex has a very high selectivity for the ion exchange resin, this means that exhaustion of the resin will take a long time, although it will still be possible to remove uranium to very low levels).

This process generates waste management issues requiring treatment, storage, or disposal of the radioactive brine, which will be a caustic or acid solution and require neutralization. Wastes can become highly concentrated and difficult to handle as anion exchange resins have a very high adsorption capacity for uranium [13].

In general, removal rates for radium and uranium range between 65 to $97 \%$ and 65 to $99 \%$, respectively. For beta emitters, the removal range is 95 to $99 \%$ [38].

Ion exchange technology was applied on a wastewater stream at Hanford, where the uranium concentration was reduced by $94 \%[13,39,40]$. Treatment of municipal drinking water with ion exchange using zeolites has reduced uranium levels by $99.7 \%$ [41] and radium levels to an average of $98 \%$ [42]. In Finland, at municipal waterworks, it was possible to reduce uranium concentration by $99.9 \%$ after treatment by a strong acid cation exchanger and a strong base anion exchanger [43]. In Bulgaria, the treatment of uranium-contaminated mine waters is carried out by ion exchange as part of the mitigation consequences from the uranium mining and processing activities [44,45]. In Germany, the Wismut Company uses this technology at two sites (Aue and Königstein) to separate uranium from flood water [46], and in Romania, ion exchange is also applied to treat 
uranium-contaminated mine waters achieving a removal rate of $99.5 \%$; radium is also removed to a certain extent [47]. A summary of these examples is presented in Table 1.

Table 1. Summary of the ion exchange (IX) performance for uranium and radium removal.

\begin{tabular}{|c|c|c|c|c|}
\hline Source for IX ${ }^{1}$ & Removal Efficiency & Mechanism & Remarks & References \\
\hline Synthetic resin & $94.0 \% \mathrm{U}$ & Anion exchanger resin & (a) & {$[13,39]$} \\
\hline DOWEX $21 \mathrm{~K}$ resin & $97-99 \%$ U & Anion exchanger resin & (b) & {$[40]$} \\
\hline Zeolites Z-92 ${ }^{\mathrm{TM}}$ resin & $99.7 \% \mathrm{U}$ & Cation exchanger & (c) & [41] \\
\hline Zeolites Z-88 ${ }^{\mathrm{TM}}$ resin & $97.3 \% \mathrm{Ra}$ & Cation exchanger & (d) & [42] \\
\hline ORWA resin & $>95 \% \mathrm{U}$ & Anion exchanger resin & (e) & [43] \\
\hline ORWA resin & $>94 \% \mathrm{Ra}$ & Cation exchanger resin & (f) & [43] \\
\hline ORWA resin & $99.9 \%$ U & Cation/Anion exchanger resin & (g) & [43] \\
\hline Synthetic resin & $99.7 \% \mathrm{U}$ & Cation exchange resin & (h) & [46] \\
\hline Synthetic resin & $99.5 \% \mathrm{U}$ & Cation exchange resin & (i) & [47] \\
\hline
\end{tabular}

${ }^{1}$ Ion Exchange identified as a Best Demonstrated Available Technology for the removal of radium-226, radium-228, and uranium.

(a) Eight cycles with an approximated uranium loading of $0.035 \mathrm{~kg} / \mathrm{kg}$ resin. The initial concentration in groundwater was $0.1 \mathrm{~kg} / \mathrm{m}^{3}$ of uranium.

(b) Changes in uranyl speciation due to $\mathrm{pH}$ variation and concentration of other groundwater constituents have a direct implication for removal efficiency.

(c) Applied successfully at several sites in the USA for drinking water treatment.

(d) Applied successfully at several sites in the USA for drinking water treatment.

(e) The uranium removal rate by a strong basic anion resin was independent of the filter type, water quality, and bed volume. The radium removal rate ranged between $35 \%$ and $65 \%$.

(f) Radium removal using a strong acidic cation resin.

(g) Removal rate using a strong acid cation exchanger followed by a strong base anion exchanger.

(h) The water treatment plant includes barium chloride treatment to remove radium and ion exchange columns to remove uranium.

(i) Radium is also removed to a certain extent.

Several examples describing the application of this method to remove other radionuclides not related to uranium mining can be found in the literature, such as the removal of tritium with an efficiency of 69 to $97 \%$ at pilot-plant testing carried out by DOE at Clemson University [48]. At the Savannah River Site, a demonstration of ion exchange to remove cesium from water achieved an efficiency of 99.9\% [49]. In bench-scale tests of self-assembled monolayers on mesoporous supports, the removal efficiencies were $99 \%$ for plutonium and cesium [50]. Groundwater treatment contaminated with technetium-99 by ion exchange using selective separation cartridges achieved removals of 70 to $94 \%$ at Ashtabula, Ohio [51].

Ion exchange technology is fully developed and has been applied to waste streams contaminated with radionuclides and metals.

\subsubsection{Chemical Precipitation}

Precipitation methods are the most widely used treatments for uranium mine and mill water effluents. They are very efficient as they use small amounts of chemicals and are low-cost. Their disadvantage is the large volume of residues produced [52].

Chemical precipitation transforms the soluble radionuclides into an insoluble form through a chemical reaction or changing the solvent's composition to reduce solubility. The chemical reaction occurs with the addition of a chemical precipitant to the aqueous waste with radionuclides in a stirred reaction vessel. A stage of sedimentation is followed where other chemicals may be added (e.g., flocculants). The most commonly used precipitants include carbonates, sulfates, sulfides, phosphates, polymers, lime, and other hydroxides. 
The process's efficiency depends on the precipitant and dosage used, the concentration of radionuclides in the aqueous waste media, and the $\mathrm{pH}$ of the solution.

This process does not reduce the mobility of the contaminants remaining in the liquid medium, although it generates a purified liquid medium. The contaminated residuals from the process (precipitated sludges) will need to be stored, further processed, or disposed of. It is considered that the chemical precipitation technology includes coagulation/filtration, in which a flocculant precipitate is formed, and lime softening that removes water hardness by the formation of insoluble calcium carbonate and magnesium hydroxide. At high $\mathrm{pH}$ levels, lime softening is very effective in removing dissolved uranium from water [37]. A generic representation of the process is shown in Figure 2.

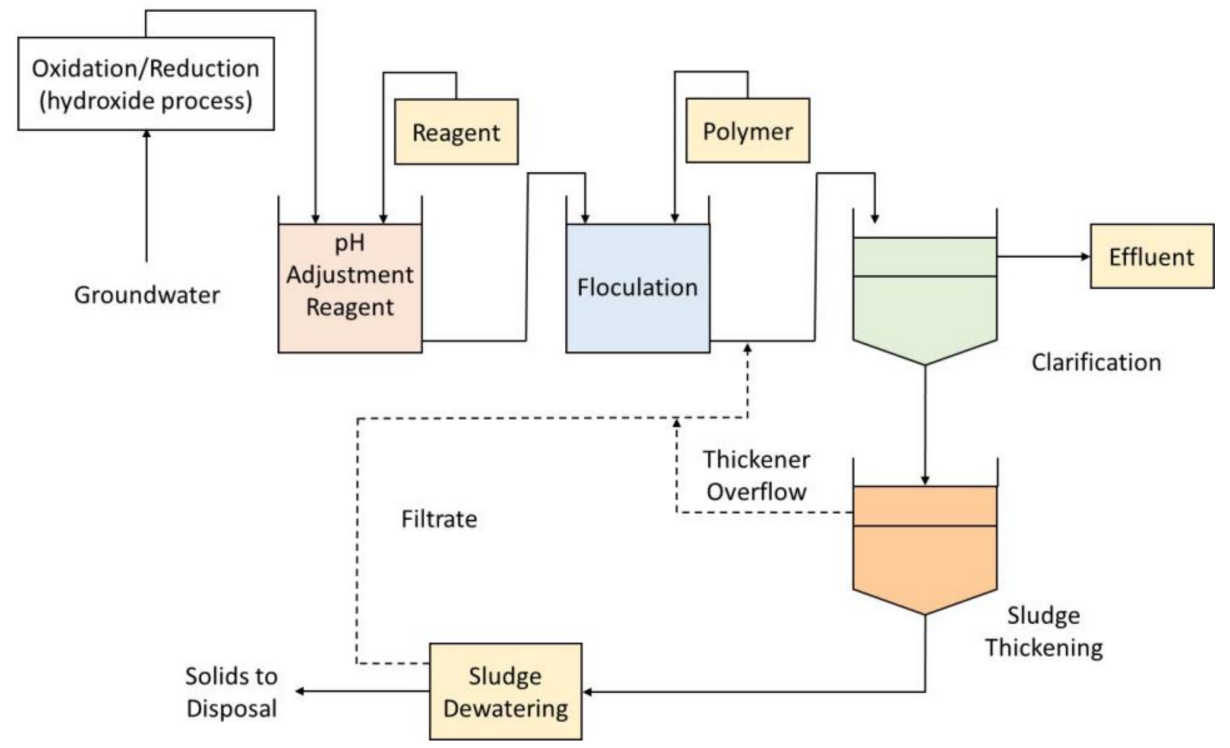

Figure 2. The general process involved in chemical precipitation [13].

This process effectively reduces high levels of radionuclides, especially radium $\left({ }^{226} \mathrm{Ra}\right.$ and ${ }^{228} \mathrm{Ra}$ ) and uranium, and dissolved metals from mine water, groundwater, surface water, wastewater, liquid waste, and leachates, using reagents and filters considering the particular radionuclide that is present.

The technology is fully developed and has been applied to liquid waste streams (including municipal water systems) contaminated with radionuclides (radium and uranium from uranium mine wastewater) and metals [53]. Nevertheless, several factors can affect the applicability and effectiveness of chemical precipitation, in particular, physical and chemical properties, such as temperature, $\mathrm{pH}$, and flow rate of the media to be treated. Also, the presence of multiple radionuclides could affect the effectiveness requiring multiple treatment processes.

When applicable, it may be necessary to adjust the $\mathrm{pH}$ of the treated effluent or remove precipitating agents. It is also necessary to dewater the sludge resulting from the precipitation before disposed of. Additional treatment may be required (e.g., sulfide removal) for treated effluents before discharged.

The bulk precipitation using lime to remove radionuclides will also remove most heavy metals from the solution. For radium, 75 to $95 \%$ removal can be achieved in the precipitation through lime softening [54].

Barium chloride is specifically used to remove radium from uranium mill process waters [55]. The removal rates are within $95-99 \%$. The precipitates (barium/radium sulfate) are challenging to retain by filtration. Therefore, it is common practice to co-precipitate radium with other more abundant species, e.g., during bulk neutralization or together with the precipitation of arsenic by ferric chloride [56]. In all precipitation processes, the precipitate is managed as radioactive waste, which requires a proper disposal strategy. 
Uranium can be removed with an efficiency of $80 \%, 92 \%$ and, $95 \%$, using ferric sulfate, ferrous sulfate, and alum, respectively [57].

Chemical precipitation is commonly used in the treatment systems for the removal of radionuclides and metals in water from mining uranium operations and sites already remediated or under remediation: Uranium Ranger mine and Olympic Dam (Australia); Wismut (Germany); Saskatchewan (Canada) [11], and is being used at DOE's Savannah River Site to remove uranium from contaminated groundwater since 2000 [58].

In the last few years, several studies have been conducted highlighting the advances in the chemical treatment of radionuclide-contaminated water in different contexts [23,59-62]. A summary of some of the mentioned case studies is presented in Table 2.

Table 2. Summary of the chemical precipitation $(\mathrm{CP})$ performance for uranium removal.

\begin{tabular}{|c|c|c|c|c|}
\hline Reagent for $\mathrm{CP}^{1}$ & Removal Efficiency & Mechanism & Remarks & References \\
\hline Ferric sulfate & $80 \% \mathrm{U}$ & Removal by coagulants & (a) & [57] \\
\hline Ferrous sulfate & $92 \% \mathrm{U}$ & Removal by coagulants & (b) & [57] \\
\hline Aluminum sulfate & $95 \% \mathrm{U}$ & Removal by coagulants & (c) & [57] \\
\hline Barium chloride & 95-99\% Ra & $\begin{array}{l}\text { Co-precipitation of barium and } \\
\text { radium sulphate }\end{array}$ & (d) & [56] \\
\hline Lime softening & $75-95 \% \mathrm{Ra}$ & Single stage softening & (e) & [54] \\
\hline Hydrogen sulfide & $99.9 \% \mathrm{U}$ & Precipitation & (f) & {$[57]$} \\
\hline Sodium hydroxide & $68.0 \% \mathrm{U}$ & Partial precipitation & (g) & [57] \\
\hline Iron chloride, sodium hydroxide & $96.7 \% \mathrm{U}$ & Co-precipitation/adsorption & (h) & [58] \\
\hline
\end{tabular}

${ }^{1}$ Chemical precipitation identified as a Best Demonstrated Available Technology for the removal of radium-226, radium-228, and uranium [13].

(a) At pH 6 and 10, the removal rate was approximately $88 \%$, but it was only $40 \%$ and $20 \%$ at $\mathrm{pH} 8$ and 4 , respectively, for the same dosage of $25 \mathrm{mg} / \mathrm{L}$ of reagent.

(b) Removal rate at $\mathrm{pH} 10$. At $\mathrm{pH} 8$ and 4, the removal rate was only $20 \%$ and $40 \%$, respectively, for the same dosage of $25 \mathrm{mg} / \mathrm{L}$ of reagent.

(c) Removal rate at $\mathrm{pH} 10$. At $\mathrm{pH} 8$ and 4 , the removal rate was only $48 \%$ and $21 \%$, respectively, for the same dosage of $25 \mathrm{mg} / \mathrm{L}$ of reagent.

(d) The best method of radium removal from sulphate rich and radium rich waters.

(e) Softening removes hardness and alkalinity; therefore, water from softening plants may change the corrosivity of the water. Conventional single stage softening can remove between 50 and $80 \%$ of radium. Enhanced lime softening can remove up to $90 \%$ of radium and uranium and may also remove arsenic, iron, and manganese.

(f) Possibility of generating a toxicity problem.

(g) No toxicity problem.

(h) Contaminant removal (metals and actinides) during neutralization and precipitation.

\subsubsection{Permeable Reactive Barriers}

A permeable reactive barrier (PRB), also known as a passive treatment wall, is an engineered barrier of reactive material placed in the subsurface designed to intercept the flow path of the contaminated plume. The barrier allows the groundwater to flow through the reactive media but retains the movement of the radionuclides [63,64] (Figure 3).

The process relies on the natural gradient to move groundwater through the barrier; therefore, there is no need for energy input and workforce into the remediation process. There is no mechanical breakdown, thus minimizing the long-term operation and maintenance costs of remediation projects.

The process involves excavating a trench perpendicular to the groundwater flow path and filling it with reactive materials, sometimes mixed with sand to increase permeability. According to the nature of the contaminants, treatment agents are selected and placed within the wall, such as chelators (specific for a given radionuclide), sorbents (peat, bone char phosphate, apatite, activated carbon, or zeolites), and reactive minerals (limestone). 
This mixture of materials should have a higher permeability than that of the aquifer to prevent hydraulic head build up and escape the plume around (or under) the barrier $[13,65]$.

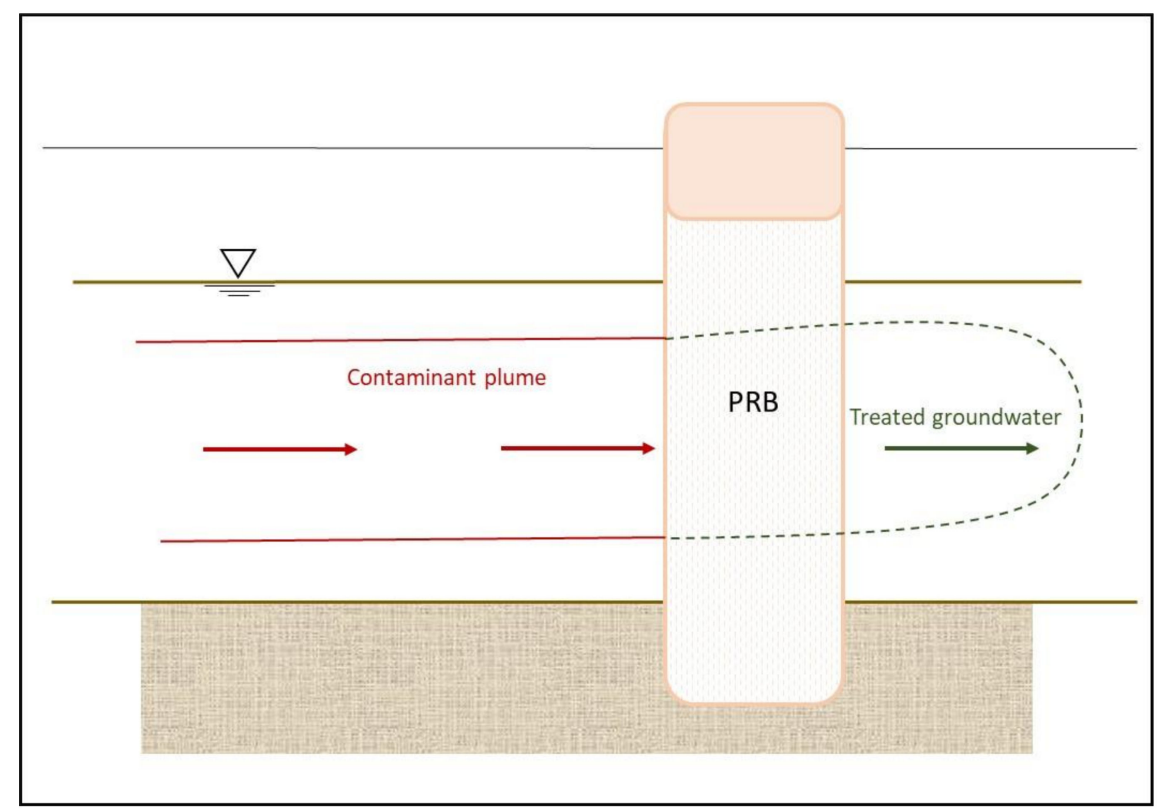

Figure 3. The layout of the process involved in permeable reactive barrier [13].

As radionuclides are retained by and concentrated within the barrier material, the treatment agents may require periodic replacement [66]. Also, the process can take several years or more for implementation, particularly in aquifers with low permeability. For that reason, the timing for achieving the remediation goals at a specific site will determine if permeable reactive barriers can be considered or not as a potential remedial technology.

There are some limitations in what concerns the applicability and effectiveness of this technology $[13,67,68]$ :

- Longer treatment time when compared with other remediation technologies (three to 30 years);

- Potential for losing reactivity of the reactive treatment material, requiring replacement of the material;

- Potential for a decrease in hydraulic conductivity of the reactive treatment material due to biological clogging and or chemical precipitation;

- Potential of plume bypassing the PRB due to seasonal fluctuations in the flow regime;

- Currently limited to shallow depths;

- The longevity of PRB performance is uncertain.

If the spent reactive media cannot be left in place, it will need to be removed. This spent media may present high radioactivity levels, depending on radionuclides and concentrations being treated, and therefore it should be managed as radioactive waste.

It is necessary to install monitoring wells upgradient, downgradient, and within the barrier wall to periodically verify the effectiveness and performance of the system and the need to replace the reactive media.

Full-scale demonstrations of this technology have been applied at several sites: Oak Ridge National Laboratory, Tennessee, (U, Tc, Sr-90) [13]; Fry Canyon, Utah (U) [69]; Chalk River Laboratories, Ontario, Canada (Sr-90) [70]. The uranium removal rates range from 60 to over $99.9 \%$ depending on the reactive media: $\mathrm{PO}_{4}=60 \%$ to $92 \%$ removal; zero-valent iron $(\mathrm{ZVI})=$ over $99.9 \%$; amorphous ferric oxyhydroxide $=37 \%$ to $90 \%$; and chabazite zeolite $=$ over $99 \%$ [13].

Over the years, permeable reactive barriers have been successfully applied to hundreds of sites for the treatment of water with metals, organic and inorganic contaminants 
but mainly in the USA [71,72]. It has been applied to a quite number of the sites with radionuclide-contaminated groundwater.

Three of these sites are given as examples, where permeable reactive barrier technology was selected to reduce the uranium concentration in groundwater as a part of the remediation approach. In the Monticello Mill Tailings site in Utah, approximately $99.9 \%$ of uranium was removed (initial concentrations of $700 \mu \mathrm{g} / \mathrm{L}$ reduced to $<0.41 \mu \mathrm{g} / \mathrm{L}$ ) with a pilot study [73]. In the Rocky Flats Environmental Technology Site in Colorado, it was possible to achieve an approximately 99\% uranium removal [74], and in the Lincoln Park site in Colorado (PRB was implemented as an interim measure), the uranium removal rate was similar $[13,75]$.

Permeable reactive barriers have been successfully used for uranium removal with zero-valent iron as the reactive media [11]. Clinoptilolite zeolite (reactive media) has shown high sorption capability for radium-226 (and also for cesium-137, strontium-90, and cobalt-60) [76].

Other studies have been developing both at bench and field-scale for better and more efficient reactive media. Laboratory and field tests were performed by Kornilovych et al. [77] at the Ukrainian Uranium Center (Zhovty Vody city, Ukraine) for the treatment of uranium-contaminated groundwater. The removal rate ranged between $60.5 \%$ and $82 \%$, using ZVI and organic carbon as treatment media. In Hungary, a pilot-scale zero-valent iron-based experimental permeable reactive barrier was built in 2002 for in situ treatment of uranium-contaminated groundwater. The six years results show that uranium is retarded by the reactive zones with very high efficiency $(>99 \%)$ [14,78]. Kumar et al. [79] investigated the use of biochar produced from switchgrass by hydrothermal carbonization as sorbent for treating uranium-contaminated groundwater. The results from the adsorption studies allowed the authors to conclude that biochar could be used as an effective adsorbent in PRB medium for U(VI), with potentially competitive low cost. Florez et al. [80] studied the applicability of clay ceramic pellets as PRBs material for the treatment of uraniumcontaminated groundwater. The results suggest that clay ceramic pellets can effectively intercept and remove uranium from contaminated groundwater $(89 \%$ was removed in the first hour with smectite minerals). A summary of these case studies is presented in Table 3.

Table 3. Summary of the permeable reactive barrier (PRB) performance for uranium removal.

\begin{tabular}{|c|c|c|c|c|}
\hline Reactive Media & Removal Efficiency & Mechanism & Remarks & References \\
\hline Bone-char phosphate $\left(\mathrm{PO}_{4}\right)$ & $60-92 \%$ & $\begin{array}{l}\text { Precipitation of an insoluble } \\
\text { uranylphosphate phase }\end{array}$ & (a) & {$[13,69]$} \\
\hline ZVI pellets & $>99.9 \%$ & Reductive precipitation & (a) & {$[13,69]$} \\
\hline $\begin{array}{l}\text { Amorphous ferric } \\
\text { oxyhydroxide (AFO) }\end{array}$ & $37-90 \%$ & $\begin{array}{l}\text { By adsorption to the iron } \\
\text { oxyhydroxide surface }\end{array}$ & (a) & {$[13,69]$} \\
\hline Gravel and ZVI & $99.9 \%$ & Reductive precipitation & (b) & {$[13,71,73]$} \\
\hline High carbon steel iron filings & $99 \%$ & Reductive precipitation & (c) & {$[13,74]$} \\
\hline ZVI & $99 \%$ & Reductive precipitation & (d) & {$[13,75]$} \\
\hline ZVI & $80-99.6 \%$ & Reductive precipitation & (e) & [13] \\
\hline ZVI and organic carbon & $60.5-82 \%$ & $\begin{array}{l}\text { Reduction, sorption, and precipitation } \\
\text { and biological reduction }\end{array}$ & (f) & [77] \\
\hline ZVI & $99 \%$ & Reductive precipitation & (g) & {$[14,78]$} \\
\hline $\begin{array}{l}\text { Biochar produced from } \\
\text { switchgrass }\end{array}$ & & Adsorption & (h) & {$[79]$} \\
\hline Clay ceramic pellets & $89 \%$ & Adsorption & (i) & [80] \\
\hline
\end{tabular}

(a) Field demonstration at Fry Canyon site. Three walls, each using different types of materials: funnel and gate design.

(b) Funnel and gate system with a three-zone PRB. During the first year of operation (1999), contaminant concentrations were reduced to non-detectable levels in groundwater passing through the system. By 2005 it was recognized that PRB has become 
ineffective in treating the groundwater due to a progressive loss of permeability. It was necessary to implement a supplemental remedy technique.

(c) The Rocky Flats Mound Site (Colorado) system (French drains, reaction vessels) was installed in 1998 and differed from a conventional barrier in that groundwater is collected in a trench lined on the downhill side with an impermeable liner. In 2006 Rocky Flats site achieved closure state.

(d) Funnel and gate design. The PRB uses zero-valent iron (ZVI) as the reactive medium to mitigate molybdenum and uranium contamination in groundwater. After less than one year of operation, uranium in the ZVI zone had remained at concentrations less than $0.006 \mathrm{mg} / \mathrm{L}$. Monitoring data suggested that molybdenum is removed from solution by ZVI but that the reaction is slower than for uranium removal.

(e) Funnel and gate design (continuous trench) installed in 1997. Removed a combination of contaminants ( $\mathrm{U}, \mathrm{Tc}$, nitric acid). After 2.5 years, significant amounts of cemented iron filings were observed in the upgradient portion of the iron (mineral precipitants are responsible for the cementation observed within the iron barrier).

(f) The PRB design consists of rows of cylinders with iron-reactive materials. Two years of monitoring data showed a reduction of uranium concentration in groundwater at the PRB site from $0.38 \mathrm{mg} / \mathrm{L}$ to $0.07-0.15 \mathrm{mg} / \mathrm{L}$. The greatest decrease was obtained using ZVI-based reactive media and the combined media of ZVI/phosphate/organic carbon combinations.

(g) Pilot-scale of a ZVI experimental permeable reactive barrier for in situ treatment of uranium-contaminated groundwater. To avoid a permeability reduction in an elemental iron barrier, the reactive matrix had to be mixed with sand.

(h) Batch adsorption experiment at the natural $\mathrm{pH}$ ( $\sim 3.9)$ of biochar. The sorption capacity was estimated to be ca. $2.12 \mathrm{mg}$ of uranium per g of biochar (H-type isotherm).

(i) Results from column experiments with clay ceramics having negatively charged sites on their surfaces which adsorb and hold positively charged uranyl ions by electrostatic force.

\subsection{Physical Separation}

Physical separation technologies are ex-situ processes requiring the construction and operation of groundwater extraction and injection system. They are based on contaminants' physical properties to separate the contaminated media into clean and contaminated fractions. The separation results in a liquid fraction and a contaminated solid residue (sludge, filter cake, or carbon adsorption unit), requiring further treatment or disposal. It can be applied to groundwater, surface water, wastewater, and slurried sludge or sediment.

The applicable processes to radionuclides present in this media, resulting from the uranium mining, are membrane filtration (reverse osmosis and microfiltration) and carbon adsorption.

\subsubsection{Membrane Filtration}

This method consists of a semi-permeable membrane to separate dissolved radionuclides or solid radionuclide particles from liquid media (e.g., groundwater, surface water). To protect the integrity of the membrane, a pretreatment (e.g., filtration of suspended solids) may be required (Figure 4). To ensure optimal conditions, water flow rate and $\mathrm{pH}$ should be controlled [11-13,81].

The process may be implemented through micro or ultrafiltration and reverse osmosis. The first two rely on the size of the pores of the membrane, while the last one is based on the selectivity of the permeable membrane. The membrane allows the water to pass through it but traps the radionuclide ions on the concentrated, contaminated liquid side of the membrane. 


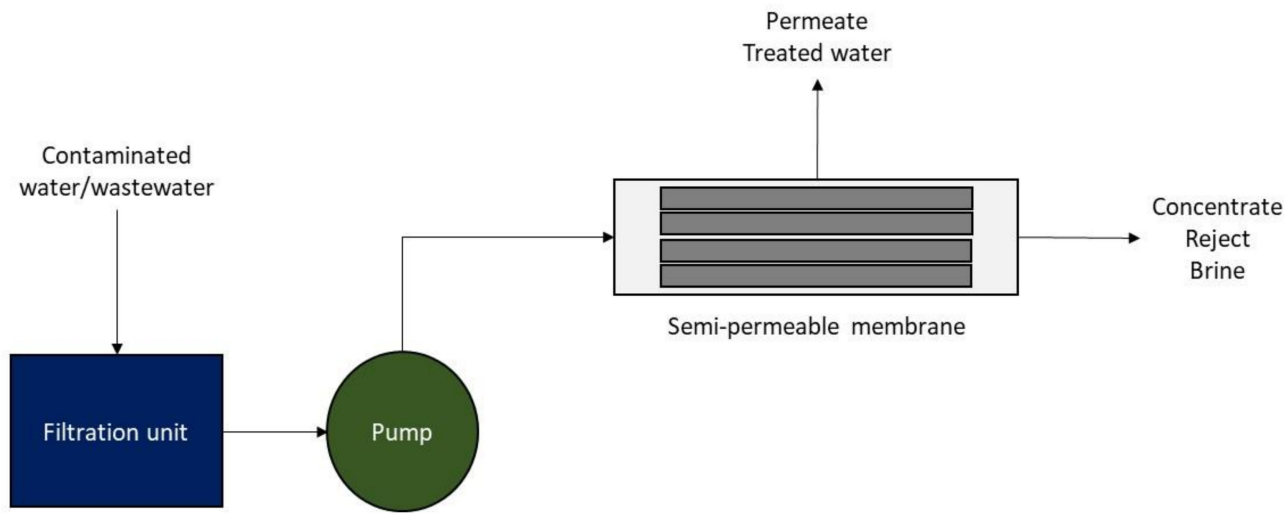

Figure 4. The layout of the general process involved in membrane filtration [13].

Micro, ultra, and nanofiltration processes work better to remove fine particles (0.001-0.1 microns). In the ultra-filtration separation, the contaminated liquid may need to be pretreated to form larger molecular complexes (e.g., metal-polymers or chelates), which are then more easily separated by the membranes [69].

For reverse osmosis, usually, the materials used as a membrane are cellulose acetate, aromatic polyamide, and thin-film composites [82]. This process is affected by the size and charge of the ion being treated. Radium and uranium ions, in particular, are large and highly charged, and thus the removal of these dissolved radionuclides from contaminated solutions is especially effective with reverse osmosis. Reverse osmosis removes molecules with diameters of 0.0001 microns or less [83].

In most membrane filtration processes, a buildup of solute (contaminant) occurs on the feed side of the membrane that needs to be controlled to maintain the efficiency of removal. Fouling of membranes may be reduced by periodic cleaning with alkalis or acids and, in the case of reverse osmosis, reversal of flow [13,84].

The membrane filtration technology may be applied to remove a variety of contaminants (metals and organics) from water and most radionuclides as well, with high efficiency (with the exception of tritium) $[2,85,86]$. Reverse osmosis has been applied for the removal of radium-226, radium-228, and uranium [57]. This process has also been identified as an effective treatment for beta emitters such as cesium-137, strontium-89, and iodine-131 [87], and it was used at DOE's Savannah River Site as the first step in a treatment process to remediate groundwater contaminated with several radionuclides (uranium, technetium, strontium, and iodine) [87].

Membrane filtration technology may be considered when radionuclide and heavy metal contaminants are associated with suspended solids in a liquid media or when precipitating agents are available for pre-treating the liquid media [88,89].

A groundwater extraction and delivery system is needed to maintain the treatment system. A pretreatment stage is required for waste solutions containing high levels of suspended solids, high or low $\mathrm{pH}$, oxidizers, or non-polar organics to avoid membrane damage. After pretreatment steps such as precipitation, flocculation, and microfiltration, reverse osmosis is sometimes used as a polishing step in a treatment train. Depending on the degree of contaminant reduction attained, the treated effluent might need additional treatment.

The micro/ultrafiltration process will generate three waste streams depending on what enters into the system: a filtrate of treated effluent, a liquid concentrate, and a filter cake of solid material with the dissolved contaminants. Reverse osmosis produces a filtrate and a liquid concentrate from treated effluent. The filter cake and liquid concentrate demand further treatment or disposal [13].

The removal rates with membrane filtration processes have been in the order of 90-99.9\% for uranium [56] and for radium in the order of 43-99\% (strongly dependent on the initial concentration) $[13,56,85,90]$. At Savannah River Site, uranium concentrations 
were reduced by $99 \%$ in the filtrate or treated effluent by microfiltration [91]. In Finland, tests carried out by the Radiation and Nuclear Safety Authority showed a uranium removal from the water of 90 to $95 \%$ using nanofiltration membranes and 98 to $99.5 \%$ using reverse osmosis membranes [92]. Bench-scale testing of membrane ultrafiltration achieved 99 to $99.9 \%$ removals of uranium and thorium [93].

Microfiltration/ultrafiltration and reverse osmosis treatments are widely used in municipal drinking water systems and industrial wastewater treatment systems [94]. In some situations, ultrafiltration and reverse osmosis are used to meet drinking water standards for radionuclides in drinking water [95-97].

Membrane processes are well-developed technologies and have been applied at both the pilot-scale and full-scale for liquids contaminated with radionuclides, although most of the time, as a treatment step within the overall treatment process. A summary of the case studies is presented in Table 4.

Table 4. Summary of the membrane filtration performance for uranium and radium removal.

\begin{tabular}{|c|c|c|c|c|}
\hline Filtration Media & Removal Efficiency & Mechanism & Remarks & References \\
\hline Spiral wound (cellulose acetate) & $99 \% \mathrm{U}$ & Reverse osmosis & (a) & [57] \\
\hline Polyamide (hollow fiber) & - & Ultrafiltration & (b) & [57] \\
\hline Spiral wound (cellulose acetate) & $99 \% \mathrm{Ra}$ & Reverse osmosis & (c) & [90] \\
\hline DuPont/Oberlin's microfiltration & $99 \%$ U & Microfiltration & (d) & {$[13,91]$} \\
\hline Polyamide (hollow fiber) & $90-95 \%$ U & Nanofiltration & (e) & {$[13,92]$} \\
\hline Spiral wound (cellulose acetate) & $98-99.5 \% \mathrm{U}$ & Reverse osmosis & (e) & {$[13,92]$} \\
\hline Membrane polymers or surfactants & $99 \% \mathrm{U}$ & Ultrafiltration & (f) & [93] \\
\hline
\end{tabular}

(a) Problems associated with fouling or membrane degradation during long-term operation.

(b) Suitable for suspended or colloidal but not for dissolved uranium.

(c) Reverse osmosis hyperfiltration removes radium to a somewhat greater extent than it does hardness. For the standard pressure modules, radium removal exceeded $99 \%$. An experimental low-pressure membrane module removed $90 \%$ of the hardness and $91 \%$ of the radium.

(d) The microfiltration system utilized DuPont's Tyvek T-980 membrane filter media in conjunction with the Oberlin automatic pressure filter. Aluminum forming and metal finishing operations generate a high content of solids, aluminum, and turbidity.

(e) Simultaneous removal ( $>95 \%$ ) of uranium, radium, lead, and polonium could be carried out by nanofiltration and reverse osmosis. The reverse osmosis side-effect was the quality of the effluent; the water becomes almost totally demineralized and therefore corrosive.

(f) Laboratory scale tests of membrane ultrafiltration in conjunction with water-soluble polymers or surfactants with added metal-selective chelating agents (membrane combined with polymers or surfactants).

\subsubsection{Adsorption}

The process involves the adsorption of dissolved contaminants on the surface and within the pores of the carbon granules [98]. It consists of pumping groundwater through a series of vessels containing granular activated carbon, which efficiency is given by its large surface to volume ratio (Figure 5). Other adsorbents may also be used, such as activated alumina (which has been demonstrated to be effective in the adsorption of uranium and radium), forager sponge, lignin adsorption/sorptive clay, and synthetic resins [99].

Carbon adsorption systems are made up of continuous flow columns set up in series. When the system is not functioning at a certain level given by the concentration of contaminants in the effluent, the carbon can be regenerated in place; removed and regenerated at an off-site facility, or removed and disposed of. For metals-contaminated groundwater, usually, the used carbon cannot be regenerated, and, in this case, it will need to be adequately managed. There are two reactor configurations commonly used for carbon 
adsorption systems: the pulsed or moving bed and the fixed bed (most widely used for adsorption from liquids) [100].

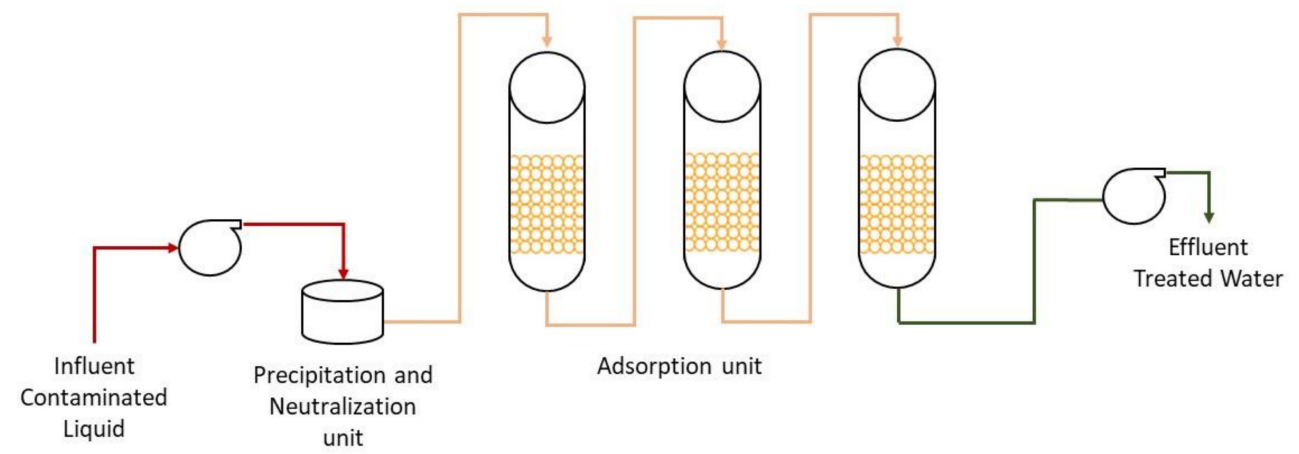

Figure 5. The general process involved in adsorption [11,13].

Granular activated carbon can be used for radionuclides such as uranium and radium226 (also, cobalt-60, ruthenium-106, and polonium-210); for organics contaminants and some inorganics as well [56,92].

Pretreatment is required in high concentrations of heavy metals and oil and grease concentrations of over ten ppm [37] which can make activated carbon ineffective and damage the system. The combination with multiple contaminants can also impact the activated carbon performance [100]. Groundwater will need to be pumped and injected after treatment. An adequate power to maintain the treatment system will be required.

The spent carbon will be replaced, further treated, or disposed of after use for the treatment of water contaminated with radionuclides. This process requires periodic monitoring to determine when activated carbon bed exhaustion has occurred and when the activated carbon must be replaced.

When radon is present in the influent, the daughter products from its decay can accumulate in the activated carbon with the possibility of elevated gamma radiation [37]. This is why this process has not been promoted for the municipal water system because the accumulation of radionuclides can be significant [57]. Nevertheless, it has been commonly used in industrial wastewater treatment systems with a removal efficiency of 90 to $99.9 \%$.

Activated carbon has been used to adsorb radium-226 and polonium-210 [56,92]. It also has been effectively used to reduce groundwater uranium concentrations with an efficiency removal between $96 \%$ and $99 \%$. Nevertheless, in this case, after several months of operation, the carbon capacity appeared to be limited [13,56].

Activated alumina has been used effectively in the adsorption of uranium (removal efficiency 90 to $99 \%$ ) and radium (removal efficiencies from 90 to $97 \%$ in pilot plant studies using manganese dioxide) $[5,54,57,101]$.

Over the years, several alternative adsorbents have been studied mostly at a laboratory scale, not only for their removal efficiency but also for their low-cost and eco-friendly performance, to remove radionuclides from liquid media [60]. The effect of several parameters on the adsorption efficiency, such as the solution $\mathrm{pH}$, contact time, initial $\mathrm{U}(\mathrm{VI})$ concentration, and temperature, is also studied.

Chen [102] used phosphate rock apatite to remove $U$ from wastewater. The highest uranium removal efficiency was $77 \%$. Police et al. [103] studied seven different types of adsorbents: tea waste, teak wood, rice husk, coconut charcoal, bentonite clay, corn cob powder, and fly ash. The results showed that tea waste had a uranium removal efficiency of 95-97\%, and fly ash had a removal efficiency of 98.5\%. Yang et al. [104] developed a composite cotton fibre composite for uranium removal from water. The efficiency of removal was approximately $88 \%$. Su et al. [105] studied the removal efficiency of U(VI) from a mining effluent by porous hydroxyapatite. The maximum efficiency was $92.6 \%$.

Patel and Clifford [22] studied the radium removal from water by manganese dioxide adsorption followed by diatomaceous-earth filtration. The removal efficiency was in the 
range of $80 \%$ to $97 \%$. Different types of zeolites, both natural (clinoptilolite) and synthetic, were recently studied for radium removal. The best efficiency of radium removal (98\%) from the water was obtained for the synthetic zeolite produced by fly ash with $\mathrm{NaOH}$ [106]. In Table 5 is presented a comparison between some of the case studies approached.

Table 5. Summary of the adsorption performance for uranium, radium, and radon removal.

\begin{tabular}{|c|c|c|c|c|}
\hline Adsorption & Removal Efficiency & Mechanism & Remarks & References \\
\hline Activated carbon & $90-99.9 \% \mathrm{Rn}$ & Adsorption & (a) & {$[13,92]$} \\
\hline Activated carbon & $97-100 \%$ U & Adsorption & (b) & {$[13,92]$} \\
\hline Activated carbon & $\sim 100 \% \mathrm{Ra}$ & Adsorption & (b) & {$[13,92]$} \\
\hline Activated carbon & $99.9 \% \mathrm{U}$ & Adsorption & (c) & {$[13,57]$} \\
\hline Titanium oxide & $96 \% \mathrm{U}$ & Adsorption & (d) & {$[57]$} \\
\hline Activated alumina & $90-99 \%$ U & Adsorption & (e) & [57] \\
\hline Manganese dioxide & $90-97 \% \mathrm{Ra}$ & Adsorption & (f) & {$[22]$} \\
\hline Phosphate rock apatite & $77 \% \mathrm{U}$ & Adsorption & (g) & [102] \\
\hline Fly ash (FA) & $98.5 \% \mathrm{U}$ & Adsorption & (h) & [103] \\
\hline Tea waste (TW) & $96 \% \mathrm{U}$ & Adsorption & (h) & [103] \\
\hline Cotton fibre composite (HCF) & $88 \% \mathrm{U}$ & Adsorption & (i) & [104] \\
\hline Porous hydroxyapatite (HAP) & $92.6 \% \mathrm{U}$ & Chemisorption & (j) & [105] \\
\hline Synthetic zeolite & $98 \% \mathrm{Ra}$ & Adsorption & $(\mathrm{k})$ & [106] \\
\hline
\end{tabular}

(a) For radon removal, a granular activated carbon filtration system was used. The adsorption process is one of purely physical adsorption. The short-lived decay products of radon are retained on the filter matrix. As a consequence, the filter matrix will emit gamma radiation.

(b) Batch experiments with seven different activated carbons derived from hard coal, brown coal, peat, wood, and coconut (7). The removal rates were different according to the types of coal: (1) $97-100 \%$; (5) 70-85\%; (1) 50\% for uranium and, (1) $100 \%$; (5) $86-94 \%$; (1) $70 \%$ for radium.

(c) Removal of uranium from municipal water. Removal rate of $97 \%$ obtained in very specific conditions (carbonate concentration and $\mathrm{pH}$ ); $75 \%$ and $<1 \%$ removal rates were also observed.

(d) Removal of uranium from municipal water. Removal rate of $96 \%$ obtained in very specific conditions (carbonate concentration and $\mathrm{pH}$ ); $93 \%, 85 \%$ and $<1 \%$ removal rates were also observed.

(e) Activated alumina can remove up to $99 \%$ of the contaminant, depending on $\mathrm{pH}$ and concentrations of competing ions. It is also effective at removing other ions such as arsenate, fluoride, sulfate, and selenite. However, when multiple contaminants are being removed, there may be issues with optimizing removal for all contaminants.

(f) Adsorption radium onto $\mathrm{MnO}_{2}$ followed by diatomaceous earth filtration. The process seems to follow a linear isotherm. Radium rate removal decreased with total hardness increase.

(g) The batch experimental results were well described by the Langmuir isotherm and Pseudo-second-order kinetic model. The uranium adsorption is found to be through a chemisorption mechanism.

(h) Adsorption of uranium on both adsorbents followed pseudo-second-order kinetics. The uranium adsorption on FA and TW is found to be a physical process. The results indicate that FA is a better adsorbent as compared to TW.

(i) Recycling experiments showed that HCF could be used up to five times with less than $10 \%$ efficiency loss.

(j) The results follow a pseudo-second-order kinetic model, suggesting that uranium adsorption is primarily attributed to chemisorption with porous HAP.

(k) A wide range of zeolites was studied for radium removal from water: natural (clinoptilolite) and synthetic (NaP1, 13X, 3A, 5A). The best efficiency of radium removal was obtained for the NaP1 type zeolite produced on the base of FA with the use of $\mathrm{NaOH}$. 


\subsection{Biological Treatment}

The treatment of radioactively contaminated groundwater, surface water, and wastewater by biological processes is done through the plant root systems and, for some radionuclides, with the transpiration to the air, through the uptake of groundwater by plants. The process is known as phytoremediation and is implemented at lower costs than conventional treatments; however, the process demands a more extended period of time to reach remediation goals. Phytoremediation uses hyper-accumulator plants and their rhizosphere microorganisms to remove, transfer, stabilize, or destroy contaminants in groundwater, surface water, or wastewater [13].

\section{Phytoremediation}

The process can be applied in-situ or ex-situ (e.g., hydroponically) to groundwater or surface water. For contaminants, in general, several phytoremediation mechanisms are available for liquid media, however as radionuclides cannot be destroyed, these mechanisms are reduced to rhizofiltration, hydraulic control, and phytovolatilization $[107,108]$, although with limited effectiveness for this type of contaminants (Figure 6).

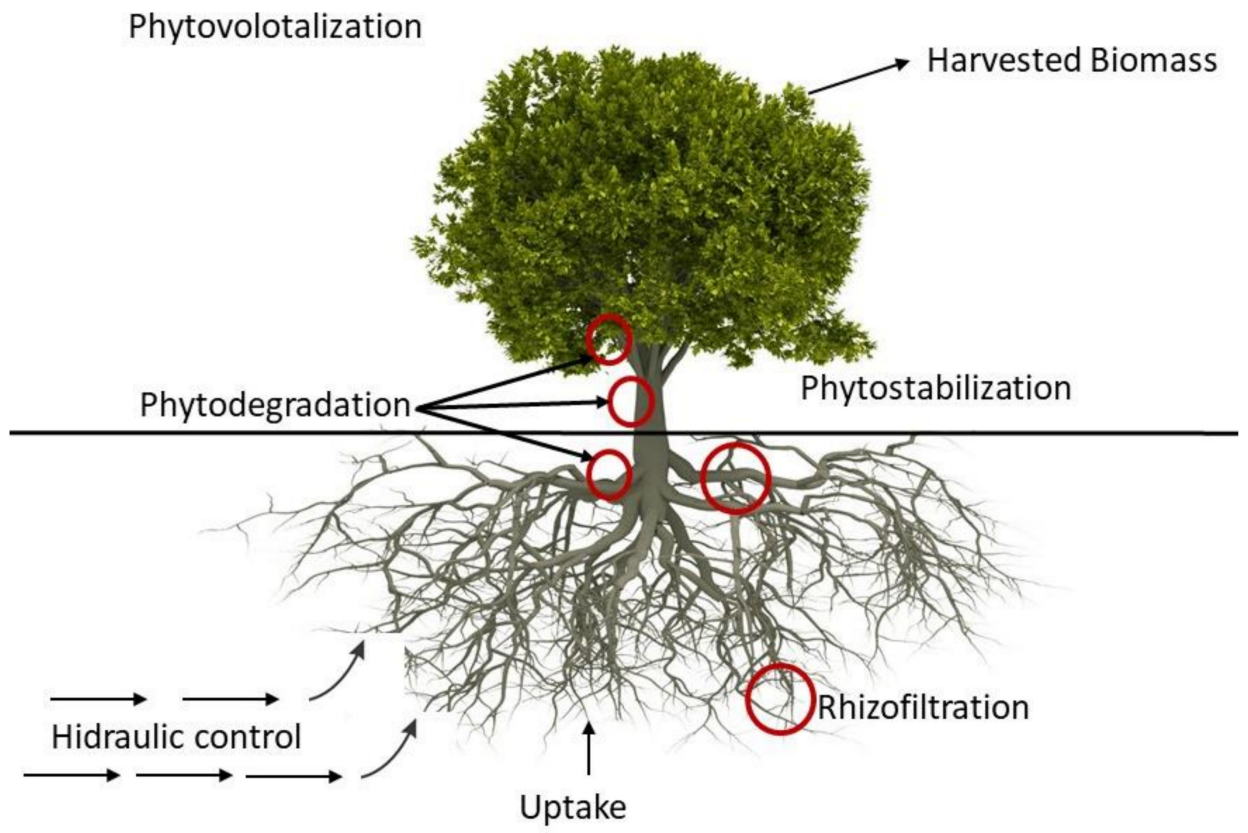

Figure 6. Phytoremediation processes [13]

In rhizofiltration, contaminants are uptake by the roots of hydroponically grown plants, translocated, and accumulated into plant shoots and leaves. Rhizofiltration has been demonstrated at several scales (bench-scale and field tests), reducing the uranium concentration effectively in water [108-111].

Rhizofiltration has been used to clean up waters contaminated with heavy metals $(\mathrm{Pb}$, $\mathrm{Cd}, \mathrm{Cu}, \mathrm{Fe}, \mathrm{Ni}, \mathrm{Mn}, \mathrm{Zn}, \mathrm{Cr}$ ) and radionuclides (U, Pu, Sr, Cs, I) [112].

In particular, the process was used to remove uranium from wastewater at DOE's Ashtabula site (Ohio) with a reduction in uranium concentration by $90 \%[13,111,113]$. It was also used to remove cesium and strontium from pond water at Chernobyl, Ukraine, with a removal efficiency of $95 \%$ for cesium and strontium.

The uranium uptake by rhizofiltration has been studied considering several aspects related to site characteristics and contaminant conditions (speciation, retention, mobility, and bioavailability phenomena), plant species, and the effect of microbial activity. Wang et al. [114] found out that $87.1 \%$ of uranium was fixed on root surfaces of common reed in a tailing wetland. However, these authors verified that the uranium complex-forming particles were not tightly adhered to the root surface but surrounding the root loosely. 
Results from laboratory-scale studies demonstrate that the rhizofiltration technique using beans efficiently removes uranium and cesium from groundwater [115]. In Portugal, macrophytes are used in the passive treatment system for water resources (surface water, groundwater, mine water) in the already rehabilitated mines. The process is part of the monitoring plan and control mine effluents to meet regulatory values limits for Utotal, $\mathrm{Ra}-226, \mathrm{Fe}$, and $\mathrm{Mn}$ [116]. In Germany, a pilot system was constructed to remove U, Ra-226, $\mathrm{As}, \mathrm{Fe}$, and $\mathrm{Mn}$ from the water of a flooded mine (Wismut) with an average $\mathrm{pH}$ of 7.3. Three years of monitoring data showed that Ra-226, As, Fe, and Mn were removed effectively and that the removal was based on the geochemical characteristics of the contaminants. The removal rates for Ra-226, As, Fe, and Mn were $70.6 \% ; 40-70 \% ; 100 \%$, and $~ 70 \%$, respectively. However, under the $\mathrm{pH}$ value of 7.3 and in the presence of high bicarbonate concentration in this mine water, uranium was not removed [117].

Phytoremediation hydraulic control consists of slowing the movement of contaminants in groundwater through the use of deep-rooted plants. This process is similar to a pump with the roots establishing a dense root mass at the water table, taking up large quantities of groundwater. The root systems should reach and grow directly into the groundwater table. Some of the trees that have been used successfully to "pump" water include poplar, cottonwood, and willow family (reaching as much as $757 \mathrm{~L}$ of water per day) [118].

The process can contain the movement of a groundwater plume toward clean areas off-site, reduce or prevent infiltration and leaching [119].

The USDOE is responsible for several former uranium mill sites concerning site characterization and groundwater remediation. Groundwater contamination at these sites resulted mostly from the large volumes of processing liquids seeped from tailings impoundments during mills operation. For these sites, evapotranspiration by native plants is evaluated to hydraulically control groundwater flow as an alternative to pump-and-treat remedies at three sites in Arizona and New Mexico [120].

One special radionuclide is tritium (although not related to uranium mining and milling activities). For tritium-contaminated plumes, the hydraulic control of groundwater plumes by plant uptake has been effectively demonstrated at Argonne National Laboratory [121,122], and the remediation of tritium-contaminated groundwater by phytovolatilization has been in operation at the Savannah River Site since 2000 [123,124].

Phytovolatilization, or phytoevaporation, is addressed to treat water with volatile or evaporable contaminants (e.g., tritium). In this process, plants uptake the contaminated water and transpire the contaminants into the air through their leaves. The root systems of the selected plants should reach and grow directly into the groundwater table.

A phytovolatilization process has been in operation at Savannah River Site (South Carolina, USA) as an enhanced-passive system since 2000. Although the process is lowenergy-consumption and low-carbon-emission, it is not completely passive. Contaminated water with tritium is collected and discharged to a dam/pond system. This water is used to irrigate a pine forest where trees uptake this water through the roots and release very low concentrations of tritium vapor into the atmosphere, where it is diluted.

This semi-passive system combines the natural processes of hydrology and evapotranspiration to reduce the volume of tritium-contaminated water entering site streams and, ultimately, the Savannah River $[31,123,124]$. The process has resulted in the reduction of tritium by $70 \%$ [31,124]. Evapotranspiration has been determined to be $80-90 \%$ effective [31].

At Argonne National Laboratory, the phytovolatilization of tritium-contaminated groundwater resulted in a reduction of the average tritium concentration by $73 \%$ over a period of three years [122].

There are a few constraints for the application of phytoremediation mechanisms to liquid media: the process is limited to shallow groundwater requiring a significant land surface area for implementation. There are also aspects that will constrain the applicability and effectiveness of phytoremediation hydraulic control, such as the confinement of shallow groundwater and the vertical flow downward of the plume [125]. 
For each case, it is necessary to perform bench-scale tests to select plant type and confirm performance [126]. Climatic or seasonal conditions will affect the growth of plants used in phytoremediation [108]. Plant toxicity effects may also occur and limit the process [82]. Also, the residue from the harvested biomass will have to be further treated or disposed of as radioactive waste [127-129]. A comparison of some of these case studies is presented in Table 6.

Table 6. Summary of the phytoremediation performance for uranium and radium removal.

\begin{tabular}{|c|c|c|c|c|}
\hline Species & Removal Efficiency & Mechanism & Remarks & References \\
\hline Sunflower (Helinathus annuus L.) & $98.9 \% \mathrm{U}$ & Rhizofiltration & (a) & {$[111,113]$} \\
\hline Sunflower (Helinathus annuus L.) & $40-45 \%$ U & Rhizofiltration & (b) & [112] \\
\hline Sunflower (Helinathus annuus L.) & $30-35 \% \mathrm{Ra}$ & Rhizofiltration & (b) & [112] \\
\hline Common reed (Phragmites australis) & $87.1 \% \mathrm{U}$ & Rhizofiltration & (c) & [114] \\
\hline Bean (Phaseolus vulgaris L. var. vulgaris) & $90.2-98.9 \%$ & Rhizofiltration & (d) & [115] \\
\hline Macrophytes (Ceratophyllum demersum) & $99 \% \mathrm{Ra}$ & Biosorption & (e) & [116] \\
\hline Macrophytes (Ceratophyllum demersum) & $89 \%$ U & Biosorption & (e) & [116] \\
\hline
\end{tabular}

(a) Rhizofiltration of uranium-contaminated water at concentrations of 21-874 $\mu \mathrm{g} / \mathrm{L}$ reduced uranium concentration to $<20 \mu \mathrm{g} / \mathrm{L}$ before discharge to the environment.

(b) Formation of precipitates in which a major part of the radionuclides are bound with the rest fixed to the roots and very low translocation to the aerial parts of the plant. For both situations, the results suggest an effect of saturation, at elimination levels of about $40-45 \%$ for uranium and $30-35 \%$ for radium.

(c) Uranium was accumulated only to a small extent within roots (rhizofiltration in sensu strictu).

(d) Laboratory scale rhizofiltration experiments. At a $\mathrm{pH}$ of 3, the ability to accumulate uranium was 1.6 times higher than it was for solutions of $\mathrm{pH} 7$ and $\mathrm{pH} 9$. Using SEM and EDS analyses, the uranium removal in solution at $\mathrm{pH} 7$ was determined based on adsorption and precipitation on the root surface in the form of insoluble uranium compounds.

(e) Results of the water resources monitoring plan and mine water control implemented in the old radioactive mines. This type of system demonstrated success, in some cases associated with groundwater natural attenuation processes for uranium, radium, and other metals.

\subsection{Natural Attenuation}

In-situ natural attenuation refers to the natural physical, chemical, and biological processes that reduce the concentration of contaminants in the subsurface [130].

Remediation of groundwater using attenuation-based technologies relies on natural processes to clean up or decrease radionuclides concentration in groundwater. These processes occur in the subsurface at most radioactively contaminated sites and include different mechanisms: abiotic degradation, dispersion, sorption, and evaporation, and radioactive decay (for some radionuclides) (Figure 7). In most cases, the source of radioactive contamination is treated or removed previously of the initiation of the process.

Natural attenuation is used within the context of a carefully controlled and monitored site cleanup approach to achieve site-specific remediation objectives. Using natural attenuation as a remedial strategy is not equivalent to 'no action' and nor is it a 'walk away' option; monitoring of these processes is to confirm that natural attenuation is taking place (Monitored Natural Attenuation-MNA), which implies a certain degree of institutional control [12]. The application of this technology can require multidisciplinary expertise in several technical areas, including radiochemistry, hydrogeology, geochemistry, and phytoremediation. 


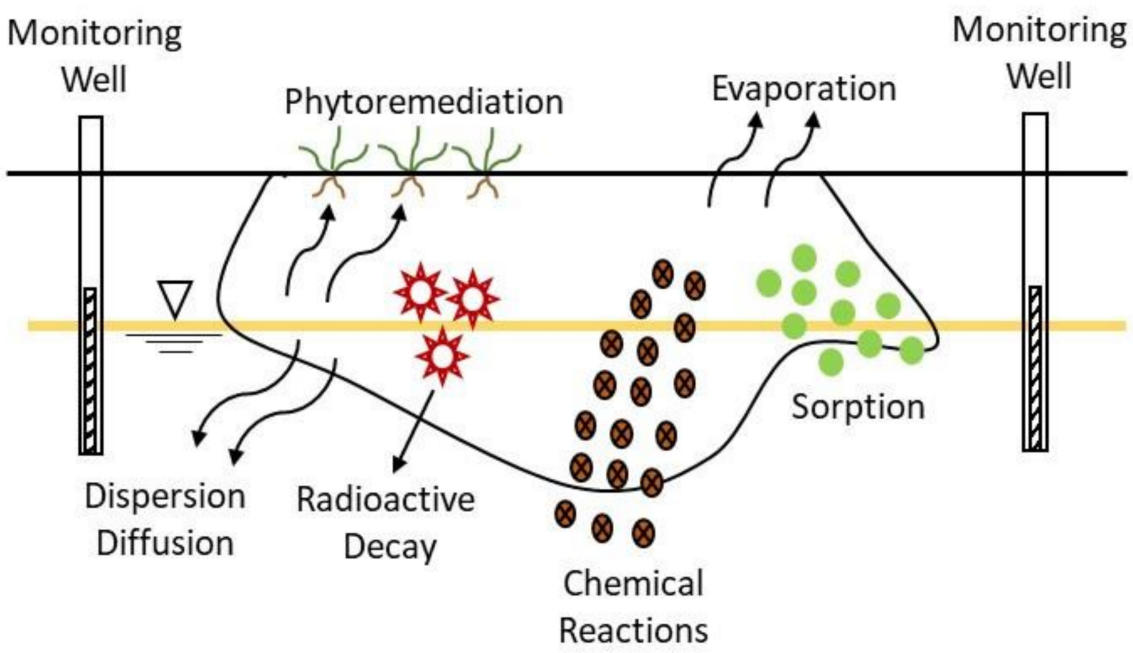

Figure 7. Mechanisms involved in the natural attenuation process [13].

Monitored Natural Attenuation

Monitored natural attenuation can be selected for the remediation of sites with different radionuclides [12], where the natural subsurface processes are able to progressively reduce radionuclide concentrations to remediation goal levels. However, it should not be applied to radionuclides with a longer half-life or more toxic and mobile daughter products [131].

Radionuclides cannot be biodegraded, but the radioactive contaminants' chemical state may be transformed by microbial action modifying their solubility and mobility, typically through coprecipitation or sorption processes [53,132]. Long-term monitoring is necessary to confirm that the contaminant reduction is occurring at rates consistent with meeting cleanup objectives [133].

Removing or containing metal or radionuclide contaminants in groundwater below specific concentrations are often inefficient and quite costly (that may still be above regulatory criteria). Also, dispersed low-level contamination may be especially challenging at many cleanup sites.

Possible changes due to geochemistry reactions that may result in the remobilization of previously stabilized contaminants must be taken into attention when considering MNA as a remedial alternative. Since with this remediation option, metal and radionuclide contaminants remain in place; MNA is generally acceptable only for sites that intrinsically have a low potential for contaminant migration. This technology is therefore coupled with institutional controls (land-use restrictions and groundwater use restrictions) and with source treatment or removals [13].

Modeling is required as well as the evaluation of radionuclide reduction rates, pathways, and prediction of the radionuclide concentration at the downgradient exposed receptor. It is necessary to demonstrate that MNA will achieve radionuclides concentrations meeting remedial goals [133]. Data for the input parameters of models is essential: soil and groundwater quality data (three-dimensional plume definition, historical data, and geochemical data), aquifer characteristics, and locations of potential receptors (wells and surface water discharge points) [133]. It is also necessary to install monitoring wells for surveillance.

Applicable regulatory policies and available technical guidance should be considered before proceeding with the application of this remediation option at radionuclides contaminate the site. It should be noted that performance monitoring and contingency plans, respectively, are required to evaluate the long-term effectiveness of the process and to provide a fallback option should the solution fail [12]. In general, monitored natural attenuation can be an appropriate remediation approach when the contaminants degrade or disperse readily, and there are no significant risks to public health and the environment 
while they attenuate, in particular when the contamination source has been removed or contained. Therefore, in general, monitored natural attenuation is not an appropriate technology when (1) the site contains a significant amount of non-aqueous phase liquids (NAPLs); (2) concentration of contaminants are so high that they represent an unacceptable threat to public health and or an ecosystem, or become toxic to microorganisms; (3) where imminent site risks are present; (4) where radionuclide levels are meaningfully above remediation goals, and (3) the rate of attenuation is unacceptably slow [18]. The timeframe for reaching the remediation goals should be compatible with anticipated future land use and groundwater use [134].

Sites with complex, heterogeneous geology, folded and faulted areas, or highly jointed rock, are not suitable for monitored natural attenuation as modeling might not predict groundwater flow, and representative monitoring and sampling might not be possible [131].

Monitored natural attenuation has been selected as the groundwater remedy option for several sites in the United States: the Teledyne Wah Chang Superfund site in Oregon (radium) [135,136]; the Hanford Site 300-Area (uranium, tritium) [137,138]; the DOE's Weldon Spring Site in Missouri (uranium) [9,139]; Monticello Mill Tailing Site (uranium) (Utah) $[61,140]$. It was also selected as the groundwater remedy option at the Savannah River Site, but for strontium. However, the behavior of an acidic-U(VI) plume was studied through reactive transport modeling evolution and long-term mobility focus on the $\mathrm{pH}$ range where $\mathrm{U}(\mathrm{VI})$ is highly mobile [31,141].

Although monitored natural attenuation has been applied at several contaminated sites with radionuclides, the information available on process rates and total reductions achieved is scarce. This lack of documented efficiency is caused, in part, by the length of the process in comparison to other remediation technologies.

In the last few years, protocols have been developed to guide evaluations of the potential for natural attenuation to occur (these protocols outline a strategy and methodology to be followed). These documents continue to increase in number over the years [142].

The US Environmental Protection Agency made available online a few toolbox screening tools that provide assistance in assessing the applicability of monitored natural attenuation at a candidate site $[143,144]$. A comparison between some of the presented case studies is shown in Table 7.

Table 7. Summary of the monitored natural attenuation (MNA) performance for uranium and radium removal.

\begin{tabular}{|c|c|c|c|c|}
\hline Contaminants & Monitoring Data (Max.) & Mechanism & Remarks & References \\
\hline Radium, VOCs, PCBs, ammonium, metals & $0.22^{1} \mathrm{~Bq} / \mathrm{L}(\mathrm{Ra})$ & Adsorption & (a) & {$[135,136]$} \\
\hline Uranium, tritium, VOCs & $3520 \mu \mathrm{g} / \mathrm{L}(\mathrm{U})$ & $\begin{array}{l}\text { Enhanced attenuation } \\
\text { (sequestration) }\end{array}$ & (b) & {$[137,138]$} \\
\hline Uranium, metals, organic compounds & $525 \mu \mathrm{g} / \mathrm{L}(\mathrm{U})$ & Adsorption & (c) & {$[9,139]$} \\
\hline Uranium and metals & $900 \mu \mathrm{g} / \mathrm{L}(\mathrm{U})$ & Adsorption & (d) & {$[61,139]$} \\
\hline Uranium, strontium, tritium, nitrates & $0.57 \mu \mathrm{g} / \mathrm{L}(\mathrm{U})$ & Adsorption & (e) & {$[31,141]$} \\
\hline
\end{tabular}

${ }^{1}$ Average data from 2010. The record of decision $(5 \mu \mathrm{g} / \mathrm{L})$ was exceeded.

(a) Site with several contaminants of concern (COCs). Some of the actual remedial actions consist of a groundwater extraction and treatment system (GETS), through granular activated carbon, with enhanced in-site bioaugmentation and monitored natural attenuation. Although GETS has reduced the concentrations of radium and COCs in groundwater, low $\mathrm{pH}$ conditions persist, contributing to COCs above cleanup levels. Between October 2002 and November 2010, on average, Ra-226 concentration in groundwater decreased from $1.15 \mathrm{~Bq} / \mathrm{L}$ to $0.22 \mathrm{~Bq} / \mathrm{L}$. Institucional controls are in place preventing exposure to contaminants of concern above cleanup goals through on-site and off-site deed restrictions on groundwater use, zoning, and access controls. The plant continues to operate, employing several hundred workers.

(b) An extensive groundwater monitoring program is operated at this site where natural attenuation is specified in the interim action to be used in conjunction with active 
remedies. The size of the tritium plume has declined due to natural attenuation, but the uranium plume is attenuating more slowly. The enhanced attenuation remedy for uranium involves injecting and infiltrating polyphosphate solutions, with the goal of sequestering residual mobile uranium that presents a continuing groundwater contamination source. This remedy was implemented in November 2015 (Stage A) and September 2018 (Stage B) for uranium.

(c) Remedial activities at the site have been completed with the exception of long-term groundwater monitoring. The adsorption of uranium onto the overburden limited its extent in groundwater. Sulfate concentrations are monitored in groundwater (an indicator of oxidation-reduction conditions). Performance monitoring locations indicate that concentrations within the area of impact are decreasing or remaining stable. However, uranium levels in monitoring wells showed seasonal variations (e.g., from 0.074 to $2.23 \mathrm{~Bq} / \mathrm{L}$ from 2011 through 2015). MNA goals are expected to require approximately 100 years to achieve. ICs are also in place to prevent groundwater from being used in restricted areas.

(d) Remedial actions to encapsulate the contamination sources were completed in 1999. MNA has reduced the concentration of most of the contaminants of concern to near or below acceptable levels; however, elevate uranium concentration persists in the alluvial aquifer (at a concentration as great as 30 times the remedial goal) even after the onset of pump-an-treat remediation. The restoration of the alluvial aquifer continues to proceed slowly. It is estimated that uranium groundwater concentrations below maximum contaminant level values will take approximately 42 years.

(e) After many years of active remediation, the groundwater remains acidic, and the concentrations of uranium and other radionuclides are still significant. MNA was not a solution to the problem. A decision was made to apply in situ treatment technologies that would lead to low $\mathrm{pH}$ and uranium. Alkaline solutions were injected into the subsurface to neutralize the acidic groundwater downgradient of the seepage basins. Monitoring downgradient of the treatment zone showed that adsorption of uranium has occurred.

\section{Conclusions}

In the past few decades, much effort has been dedicated to the remediation of radioactively contaminated sites worldwide. Several countries have initiated programs to assess and remediate radionuclide-contaminated sites from several industrial activities. Therefore, much experience has been gained over the past decades in the use of control and treatment technologies applied to different configurations and types of contaminated sites. There is a wide range of demonstrated and industrial proven remediation technologies or combinations of remediation technologies and their variations to suit particular radionuclide contaminated-site conditions. However, it has been recognized that many techniques and technologies may be too costly to implement on a large scale or may be inadequate to address the magnitude and combinations of contamination problems at a specific site. Also, it is important to stress out that there is no universal remediation plan. Moreover, a great effort is required to organize the remediation work to best utilize the available resources and taking the greatest advantage of technology research and development. International organizations (e.g., the International Atomic Energy Agency and the US Environmental Protection Agency) made a lot of effort to provide guides and recommendation for different remediation approaches based on research studies, practical experience, case studies and lessons learned.

For the remediation technologies applicable to radionuclide-contaminated groundwater, even for those well-developed and implemented at full scale, several issues remain unresolved. Transforming some radionuclides (e.g., uranium) into a harmless and stable form is a way forward in contamination control and reduction. More mobile radionuclides require more effective methods or the improvement of the efficiency of the existing ones, also to reduce the generation of water treatment residues (secondary wastes). The further 
treatment or the safe and long-term stable disposal of these wastes (usually large volume) should be integrated into the overall treatment concept. For some of these methods (mostly passive or semi-passive systems), the window of applicability is relatively narrow. It may not comply with regulatory constraints at several levels, such as insufficient reliability and time of performance to achieve remediation goals.

Author Contributions: Conceptualization, M.d.L.D.; methodology, M.d.L.D.; validation, M.d.L.D. and A.F.; formal analysis, M.d.L.D.; investigation, M.d.L.D.; resources, M.d.L.D.; writing-original draft preparation, M.d.L.D.; writing—review and editing, M.d.L.D. and A.F.; funding acquisition, M.d.L.D. and A.F. All authors have read and agreed to the published version of the manuscript.

Funding: This work was financially supported by: Base Funding-UIDB/04028/2020 of the Research Center for Natural Resources and Environment-CERENA—funded by national funds through the FCT / MCTES (PIDDAC).

Conflicts of Interest: The authors declare no conflict of interest.

\section{References}

1. Beneš, P. The Environmental Impacts of Uranium Mining and Milling and the Methods of Their Reduction. In Chemical Separation Technologies and Related Methods of Nuclear Waste Management; Choppin, G.R., Khankhasayev, M.K., Eds.; NATO Science Series (Series 2: Environmental Security); Springer: Dordrecht, The Netherlands, 1999; Volume 53. [CrossRef]

2. Nuclear Energy Agency. Managing Environmental and Health Impacts from Uranium Mining; No. 7062; OECD: Paris, France, 2014.

3. Heard, B. Environmental Impacts of Uranium Mining in Australia, History, Progress and Current Practice. Minerals Council of Australia. 2007. Available online: https://minerals.org.au/sites/default/files/Environmental $\% 20$ impacts $\% 20$ of $\% 20$ uranium $\% 20$ mining\%20in\%20Australia_May\%202017_WEB.pdf (accessed on 3 June 2021).

4. Interstate Technology \& Regulatory Council. PRB-5 Permeable Reactive Barrier: Technology Update. PRB-5. Washington, DC: Interstate Technology \& Regulatory Council, PRB: Technology Update. 2011. Available online: https://connect.itrcweb.org/ HigherLogic/System/DownloadDocumentFile.ashx?DocumentFileKey=fd058d3e-9bdc-4103-8f13-4195efa8499f (accessed on 19 April 2021).

5. Patel, R.; Clifford, C. Radium Removal from Water by Manganese Dioxide Adsorption and Diatomaceous Erath Filtration; Project Summary, EPA/600/S2-91/063; EPA: Washington, DC, USA, 1992.

6. U.S. Department of Energy. Innovative Technology Summary Report: Permeable Reactive Treatment (PeRT) Wall for Rads and Metals. Subsurface Contaminants Focus Area. September 2000. DOE/EM-0557. Available online: https://frtr.gov/ costperformance/pdf/Monticello_PeRTWall.pdf (accessed on 3 June 2021).

7. U.S. Environmental Protection Agency. Atomic Energy of Canada, Limited (Chemical Treatment and Ultrafiltration). Superfund Innovative Technology Evaluation Program, Technology Profiles, Tenth Edition. August 2000. EPA/540/C-99/500. Available online: https: / / semspub.epa.gov/work/01/568445.pdf (accessed on 3 June 2021).

8. Simon, F.G.; Meggyes, T.; McDonald, C. Advanced Groundwater Remediation. Active and Passive Technologies, 1st ed.; Thomas Telford Publishing, Thomas Telford Ltd.: London, UK, 2002. Available online: http:/ / www.thomastelford.com (accessed on 19 April 2021).

9. U.S. Environmental Protection Agency. EPA Superfund Record of Decision: Weldon Spring, Quarry/Plant/Pits (USDOE/Army), EPA ID: MO3210090004, OU 6, St. Charles County, Mo., 02/20/2004. EPA/ROD/R07-04/036. Available online: https:/ / semspub. epa.gov/work/HQ/187957.pdf (accessed on 3 June 2021).

10. U.S. Environmental Protection Agency. EPA Superfund Record of Decision: Savannah River Site, (USDOE), EPA ID: SC1890008989, OU 12, Aiken, S.C., 03/10/2004. EPA/ROD/R04-04/007. Available online: https://semspub.epa.gov/work/HQ/187052.pdf (accessed on 3 June 2021).

11. International Atomic Energy Agency. Treatment of Liquid Effluent from Uranium Mines and Mills. Report of a Co-Ordinated Research Project, 1996-2000; IAEA-TECDOC-1419; IAEA: Vienna, Austria, 2004.

12. International Atomic Energy Agency. Applicability of Monitored Natural Attenuation at Radioactively Contaminated Sites; Technical Reports Series No. 445, STI/DOC/010/445; IAEA: Vienna, Austria, 2006.

13. U.S. Environmental Protection Agency. Technology Reference Guide for Radioactively Contaminated Media, EPA 402-R-07-004. 2007. Available online: https:/ / www.epa.gov/sites/production/files/2015-05/documents/media.pdf (accessed on 3 June 2021).

14. Csővári, M.; Földing, G.; Csicsák, J.; Frucht, É. Experience gained from the experimental permeable reactive barrier installed on the former uranium mining site. In Uranium, Mining and Hydrogeology; Merkel, B.J., Hasche-Berger, A., Eds.; Springer: Berlin/Heidelberg, Germany, 2008. [CrossRef]

15. Litter, M. Treatment of Chromium, Mercury, Lead, Uranium, and Arsenic in Water by Heterogeneous Photocatalysis. In Advances in Chemical Engineering; de Lasa, H.I., Rosales, B.S., Eds.; Academic Press: Cambridge, MA, USA, 2009; Volume 36, pp. 37-67. [CrossRef] 
16. U.S. Environmental Protection Agency. Monitored Natural Attenuation of Inorganic Contaminants in Ground Water Technology, EPA/600/R-10/093, 2010; Volume 3, Assessment for Radionuclides Including Tritium, Radon, Strontium, Technetium, Uranium, Iodine, Radium, Thorium, Cesium, and Plutonium-Americium. Available online: https://semspub.epa.gov/work/HQ/153375 .pdf (accessed on 3 June 2021).

17. Interstate Technology \& Regulatory Council. A Decision Framework for Applying Monitored Natural Attenuation Processes to Metals and Radionuclides in Groundwater. APMR-1. Washington, DC: Interstate Technology \& Regulatory Council, Attenuation Processes for Metals and Radionuclides. 2010. Available online: https://connect.itrcweb.org/HigherLogic/System/ DownloadDocumentFile.ashx?DocumentFileKey=0e667759-d96a-45d3-a2b5-f831b2d4b961 (accessed on 19 April 2021).

18. Yeung, A.T. Remediation Technologies for Contaminated Sites. In Advances in Environmental Geotechnics; Chen, Y., Zhan, L., Tang, X., Eds.; Springer: Berlin/Heidelberg, Germany, 2010. [CrossRef]

19. Wan, J.; Dong, W.; Tokunaga, T.K. Method to Attenuate U(VI) Mobility in Acidic Waste Plumes Using Humic Acids. Environ. Sci. Technol. 2011, 45, 2331-2337. [CrossRef] [PubMed]

20. Dresel, P.E.; Wellman, D.M.; Cantrell, K.J.; Truex, M.J. Review: Technical and Policy Challenges in Deep Vadose Zone Remediation of Metals and Radionuclides. Environ. Sci. Technol. 2011, 45, 4207-4216. [CrossRef] [PubMed]

21. Daniel, M.; Ollivier, D.; Merten, D.; Bochel, G.; Bergman, H.; Willscher, S.; Jablonski, L.; Wittig, J.; Werner, P. The New Uranium Mining Boom: Challenges and Lessons Learned; Springer: Berlin/Heidelberg, Germany, 2011; Part 3; pp. 433-442, ISBN 978-3-64222121-7.

22. Patel, R.; Clifford, D. Radium Removal from Water by Manganese Dioxide Adsorption and Diatomaceous-Earth Filtration Final Report (PB-92-115260/XAB). United States. 1991. Available online: https://www.osti.gov/biblio/5865700-radium-removalfrom-water-manganese-dioxide-adsorption-diatomaceous-earth-filtration-final-report (accessed on 3 June 2021).

23. Borch, T.; Roche, N.; Johnson, T.E. Determination of contaminant levels and remediation efficacy in groundwater at a former in situ recovery uranium mine. J. Environ. Monit. 2012, 14, 1814-1823. [CrossRef] [PubMed]

24. Vokál, V.; Mužák, J.; Ekert, V. Remediation of Uranium In-Situ Leaching Area at Stráž pod Ralskem, Czech Republic. In Proceedings of the ASME 2013 15th International Conference on Environmental Remediation and Radioactive Waste Management, Brussels, Belgium, 8-12 September 2013. [CrossRef]

25. Willscher, S.; Wittig, J.; Bergmann, H.; Büchel, G.; Merten, D.; Werner, P. Phytoremediation as an Alternative Way for the Treatment of Large, Low Heavy Metal Contaminated Sites: Application at a Former Uranium Mining Area. Adv. Mater. Res. 2009, 71-73, 705-708. [CrossRef]

26. Phillips, E.; Yarmak, E. Frozen Soil Barrier Technology—Facts about the Oak Ridge National Laboratory Barrier-14554. In Proceedings of the WM 20104 Conference, Phoenix, AZ, USA, 2-6 March 2014.

27. Truex, M.J.; Jonhnson, C.D.; Becker, D.J.; Lee, M.H.; Nimmons, M.J. Performance Assessment for Pump-and-Treat Closure or Transition. Pacific Northwest National Laboratory PNNL-24696, RPT-DVZ-AFRI-029. 2015. Available online: https:/ /www.pnnl. gov/main/publications / external/technical_reports/PNNL-24696.pdf (accessed on 3 June 2021).

28. Rosenberg, E.; Pinson, G.; Tsosie, R.; Tutu, H.; Cukrowska, E.; Edward, R.; Glenn, P.; Ranalda, T.; Hlanganani, T.; Ewa, C. Uranium Remediation by Ion Exchange and Sorption Methods: A Critical Review. Johns. Matthey Technol. Rev. 2016, 60, 59-77. [CrossRef]

29. Zhang, X.; Gu, P.; Liu, Y. Decontamination of radioactive wastewater: State of the art and challenges forward. Chemosphere 2019, 215, 543-553. [CrossRef]

30. Denham, M.E.; Amidon, M.B.; Wainwright, H.M.; Dafflon, B.; Ajo-Franklin, J.; Eddy-Dilek, C.A. Improving Long-term Monitoring of Contaminated Groundwater at Sites where Attenuation-based Remedies are Deployed. Environ. Manag. 2020, 66, 1142-1161. [CrossRef]

31. Savannah River Nuclear Solutions, LLC. Savannah River Site Groundwater Management Strategy and Implementation Plan (U). WSRC-RP-2006-4074. 2020. Available online: https://www.srs.gov/general/programs/soil/gen/gw_mgmt_strategy_and_ implementation_plan.pdf (accessed on 3 June 2021).

32. Nedjimi, B. Phytoremediation: A sustainable environmental technology for heavy metals decontamination. SN Appl. Sci. 2021, 3, 286. [CrossRef]

33. Li, C.; Ji, X.; Luo, X. Phytoremediation of Heavy Metal Pollution: A Bibliometric and Scientometric Analysis from 1989 to 2018. Int. J. Environ. Res. Public Health 2019, 16, 4755. [CrossRef]

34. Nariyan, E.; Sillanpää, M.; Wolkersdorfer, C. Uranium removal from Pyhäsalmi/Finland mine water by batch electrocoagulation and optimization with the response surface methodology. Sep. Purif. Technol. 2018, 193, 386-397. [CrossRef]

35. Hossain, F. Natural and anthropogenic radionuclides in water and wastewater: Sources, treatments and recoveries. J. Environ. Radioact. 2020, 225, 106423. [CrossRef]

36. Zaheri, A.; Mohed, A.; Keshtkar, R.A.; Shirani, A.S. Uranium Separation from Wastewater by Electrodialysis. Iran. J. Environ. Health. Sci. Eng. 2010, 7, 429-436.

37. Kapline Enterprises Inc. Aqueous-Stream Uranium-Removal Technology Cost/Benefit and Market Analysis. Prepared for U.S. Department of Energy, Office of Technology Development, March 1994. DOE/OR-2006. Available online: https://inis.iaea.org/ collection/NCLCollectionStore/_Public/30/057/30057666.pdf (accessed on 3 June 2021).

38. Oak Ridge National Laboratory. Y-12 Plant Remedial Action Technology Logic Diagram, Volume 3, Technology Evaluation Data Sheets, Part A, Remedial Action, 1994. Y/ER-161/V3/PtA. Available online: https://inis.iaea.org/collection/ NCLCollectionStore/_Public/29/015/29015704.pdf?r=1\&r=1 (accessed on 3 June 2021). 
39. U.S. Department of Energy. Decommissioning Handbook. Office of Environmental Restoration, March 1994. DOE/EM-0142. Available online: https:/ / www.nrc.gov/docs/ML1108/ML110800146.pdf (accessed on 3 June 2021).

40. Campbell, E.L.; Levitskaia, T.G.; Fujimoto, M.S.; Holfeltz, V.E.; Chatterjee, S.D.; Hall, G.B. Analysis of Uranium Ion Exchange Resin from the 200 West Pump-and-Treat Facility. Prepared for U.S. Department of Energy under the Contract DE-AC05-76RL01830. Available online: https:/ / www.osti.gov/servlets/purl/1488863 (accessed on 3 June 2021).

41. Water Remediation Technology. Pilot Study Report for Z-Uranium Treatment Process Conducted at the Mountain Water \& Sanitation District, Conifer, Colo. Revised 11 November 2004. Available online: https://www.wrtnet.com/category/pilotstudies/uranium-pilot-studies/ (accessed on 3 June 2021).

42. Water Remediation Technology. Pilot Study Report for Z-Radium Treatment Process Conducted at the Richland Special Utility District Richland Springs, Texas. 18 May 2004. Available online: https:/ / www.wrtnet.com/category/pilot-studies/radium-pilotstudies / (accessed on 3 June 2021).

43. Salonen, L.; Turunen, H.; Mehtonen, J.; Mjönes, L.; Hagberg, N.; Wilken, R.; Raff, O. Removal of Radon by Aeration: Testing of Various Aeration Techniques for Small Water Works. Radiation and Nuclear Safety Authority of Finland (STUK), Helsinki, 2002. Report No. STUK-A193. Available online: https:// core.ac.uk/download/pdf/33459481.pdf (accessed on 3 June 2021).

44. Dinis, M.L.; Fiúza, A. Overview of the Long-Term Stewardship of the Remediated Uranium Mining and Milling Sites in Europe-20079. In Proceedings of the WM2020, Phoenix, AZ, USA, 8-12 March 2020.

45. Sixth National Report Fulfilment of the Obligations under the Joint Convention on the Safety of Spent Fuel Management an on the Safety of Radioactive Waste Management, Sofia, Bulgaria. 2017. Available online: https://www.iaea.org/sites/default/files/ national_report_of_bulgaria_for_the_6th_review_meeting_-_english.pdf (accessed on 3 June 2021).

46. Sixth National Report Fulfilment of the Obligations under the Joint Convention on the Safety of Spent Fuel Management and on the Safety of Radioactive Waste Management, Report of the Federal Republic of Germany for the Sixth Review Meeting. May 2018. Available online: https://www.bmu.de/fileadmin/Daten_BMU/Download_PDF/Nukleare_Sicherheit/jc_6_bericht_ deutschland_en_bf.pdf (accessed on 3 June 2021).

47. European Commission, Uranium Mining, Processing, Fuel Fabrication and National Monitoring Networks, Romania, Technical Report, Verifications under the Terms of Article 35 of the EURATOM Treaty, RO-12/05 (2012). Available online: https:/ / ec.europa. eu/energy/sites/default/files/documents/tech_report_romania_2012_en.pdf (accessed on 3 June 2021).

48. Jeppson, D.W. Separation of Tritium from Wastewater. In Proceedings of the WM2000 Conference, Tucson, AZ, USA, 27 February-3 March 2000.

49. Oji, L.; Thompson, M.; Peterson, K.; May, C.; Kafka, T. Cesium Removal from R-Reactor Building Disassembly Basin Using 3M®Empore Web-Membrane Filter Technology. Prepared by Westinghouse Savannah River Company for U.S. Department of Energy, 1998. WSRC-TR-98-00209. Available online: https://digital.library.unt.edu/ark:/67531/metadc679901/ (accessed on 19 April 2021).

50. Fryxell, G. Final Report: Actinide-Specific Interfacial Chemistry of Monolayer Coated Mesoporous Ceramics. Prepared by Pacific Northwest National Laboratory for U.S. Department of Energy, Report No. EMSP-65370. September 2001. Available online: https:/ / digital.library.unt.edu/ark:/67531/metadc779176/m2/1/high_res_d/833249.pdf (accessed on 3 June 2021).

51. Hoffman, K. Radionuclide Capture Using Membrane Technology. In Proceedings of the FETC Industry Partnerships to Deploy Environmental Technology Conference, Morgantown, WV, USA, 12-14 October 1999.

52. Gusek, J.J.; Figueroa, L.A. Mitigation of Metal Mining Influenced Water. In Management Technologies for Metal Mining Influenced Water; Gusek, J.J., Figueroa, L.A., Eds.; Society for Mining, Metallurgy, and Exploration, Inc. (SME): Englewood, CO, USA, 2007; Volume 2, pp. 85-109.

53. International Atomic Energy Agency. Review of the Factors Affecting the Selection and Implementation of Waste Management Technologies; IAEA-TECDOC-1096; IAEA: Vienna, Austria, 1999.

54. Sorg, T. Treatment of Radioactive Compounds in Water. Radioactive Site Remediation Technologies Seminar, Speaker Slide Copies; EPA/540/K-92/001; EPA Office of Research and Development: Washington, DC, USA, 1992.

55. Nuclear Energy Agency. Environmental Remediation of Uranium Production Facilities. A Joint Report by the OECD Nuclear Energy Agency and the International Atomic Energy Agency; OECD: Paris, France, 2002.

56. Chałupnik, S.; Wysocka, M.; Chmielewska, I.; Samolej, K. Modern technologies for radium removal from water-Polish mining industry case study. Water Resour. Ind. 2020, 23, 100125. [CrossRef]

57. Sorg, T.J. Methods for Removing Uranium from Drinking Water. J. Am. Water Work. Assoc. 1988, 80, 105-111. [CrossRef]

58. Serkiz, S.; Rebout, S.; Bell, N.; Kanzleiter, J.; Bohrer, S.; Lovekamp, J.; Faulk, G. Reengineering Water Treatment Units for Removal of Sr-90, I-129, Tc-99, and Uranium from Contaminated Groundwater at the DOE's Savannah River Site. Prepared by Westinghouse Savannah River Company for U.S. Department of Energy, 2000. WSRC-MS-2000-00097. Available online: https: / / semspub.epa.gov/work/HQ/175254.pdf (accessed on 3 June 2021).

59. Tokunaga, T.; Kim, Y.; Wan, J. Potential Remediation Approach for Uranium-Contaminated Groundwaters through Potassium Uranyl Vanadate Precipitation. Environ. Sci. Technol. 2009, 43, 5467-5471. [CrossRef] [PubMed]

60. WenChao, Y.; Yadan, G.; Bai, G.; Ping, L. Research Advances of Chemical Treatment of Wastewater with Low Concentration of Uranium. In Proceedings of the 4th International Conference on Machinery, Materials and Computing Technology (ICMMCT), Hangzhou, China, 23-24 January 2016. 
61. Cujic, M.; Petrovic, J.; Dragovic, S. Review of Remediation Approaches Implemented in Radioactively Contaminated Areas. In Remediation Measures for Radioactively Contaminated Areas; Gupta, D.K., Voronina, A., Eds.; Springer International Publishing AG: Cham, Switzerland, 2019; pp. 1-9. [CrossRef]

62. Szenknect, S.; Mesbah, A.; Descostes, M.; Maihatchi-Ahamed, A.; Bonato, L.; Massonnet, M.; Ziouane, Y.; Vors, E.; Vercouter, T.; Clavier, N.; et al. Uranium removal from mining water using Cu substituted hydroxyapatite. J. Hazard. Mater. 2020, $392,122501$. [CrossRef] [PubMed]

63. Vidic, R.D.; Pohland, F.G. In situ Groundwater Remediation Using Treatment Walls. In Emerging Technologies in Hazardous Waste Management 8; Tedder, D.W., Pohland, F.G., Eds.; Kluwer Academic Publishers: New York, NY, USA, 2002; pp. 119-139. [CrossRef]

64. Palmer, P.L. Permeable treatment barriers. In Situ Treatment Technology, 2nd ed.; Lewis Publishers: Boca Raton, FL, USA, 2001; pp. $459-482$.

65. U.S. Environmental Protection Agency. Permeable Reactive Barrier Technologies for Contaminant Remediation. Office of Research and Development, Office of Solid Waste and Emergency Response, September 1998b. EPA/600/R-98/125. Available online: https: / / clu-in.org/download/rtdf/prb/reactbar.pdf (accessed on 3 June 2021).

66. Federal Remediation Technologies Roundtable. Remediation Technologies Screening Matrix and Reference Guide, Version 4.0: Passive/Reactive Treatment Walls. 2002. Available online: http://www.frtr.gov/matrix2/section4/4-41.html (accessed on 3 June 2021).

67. Sharma, H.D.; Reddy, K.R. Geoenvironmental Engineering; John Wiley \& Sons: Hoboken, NJ, USA, 2004.

68. Henderson, A.D.; Demond, A.H. Long-Term Performance of Zero-Valent Iron Permeable Reactive Barriers: A Critical Review. Environ. Eng. Sci. 2007, 24, 401-423. [CrossRef]

69. U.S. Environmental Protection Agency. Field Demonstration of Permeable Reactive Barriers to Remove Dissolved Uranium From Groundwater, Fry Canyon, Utah, September 1997 through September 1998, Interim Report. Office of Air and Radiation, November 2000. EPA/402/C-00/001. Available online: https:/ /www.epa.gov/sites/production/files/2015-05/documents/402c-00-001.pdf (accessed on 3 June 2021).

70. U.S. Environmental Protection Agency. Cost and Performance Report-Permeable Reactive Barriers Interim Summary Report: Permeable Reactive Barriers Using Continuous Walls to Treat Metals, May 2002. Office of Solid Waste and Emergency Response, Technology Innovation Office, 2002b. Available online: https:/ / frtr.gov/costperformance/pdf/continuouswallformetals.pdf (accessed on 3 June 2021).

71. U.S. Environmental Protection Agency. EPA Superfund Record of Decision: Monticello Mill Tailings (USDOE), EPA ID: UT3890090035, OU 3, Monticello, Utah, 09/29/1998. EPA/ROD/R08-98/106. 1998. Available online: https://semspub. epa.gov/work/HQ/188239.pdf (accessed on 19 April 2021).

72. Blowes, D.W.; Ptacek, C.J.; Benner, S.G.; McRae, C.W.; Bennett, T.A.; Puls, R.W. Treatment of inorganic contaminants using permeable reactive barriers. J. Contam. Hydrol. 2000, 45, 123-137. [CrossRef]

73. U.S. Department of Energy. First Five-Year Review Report for Monticello Mill Tailings Site, San Juan County Monticello, Utah, June 2017. Prepared by U.S. DOE, Legacy Management, for U.S. EPA, LMS/MNT/S14775. Available online: https: / / www.lm.doe.gov/Monticello/Documents.aspx (accessed on 3 June 2021).

74. U.S. Department of Energy. First Five-Year Review Report for Rocky Flats Environmental Technology Site, Golden, Colorado, July 2002a. Prepared by U.S. DOE, Rocky Flats Field Office for U.S. EPA. Available online: https://semspub.epa.gov/work/08/6 1084.pdf (accessed on 3 June 2021).

75. U.S. Environmental Protection Agency. EPA Superfund Record of Decision: Lincoln Park, EPA ID: COD042167858, OU 02, Canon City, Colo., 01/03/2002, 2002a. EPA/ROD/R08-02/108. Available online: https://semspub.epa.gov/work/08/490323.pdf (accessed on 3 June 2021).

76. U.S. Environmental Protection Agency. Evaluating Performance of the Monticello PRB in Treating Uranium and Metals. Technology News and Trends, July 2003. EPA CLU-IN Newsletter. Available online: http:/ / clu-in.org (accessed on 3 June 2021).

77. Kornilovych, B.; Wireman, M.; Ubaldini, S.; Guglietta, D.; Koshik, Y.; Caruso, B.; Kovalchuk, I. Uranium Removal from Groundwater by Permeable Reactive Barrier with Zero-Valent Iron and Organic Carbon Mixtures: Laboratory and Field Studies. Metals 2018, 8, 408. [CrossRef]

78. Roehl, K.E.; Meggyes, T.; Simon, F.G.; Stewart, D.J. Long-term Performance of Permeable Reactive Barriers. In Trace Metals and other Contaminants in the Environment; Nriagu, J.P., Ed.; Elsevier: Leeds, UK, 2005; Volume 7.

79. Kumar, S.; Loganathan, V.A.; Gupta, R.B.; Barnett, M.O. An Assessment of U(VI) removal from groundwater using biochar produced from hydrothermal carbonization. J. Environ. Manag. 2011, 92, 2504-2512. [CrossRef]

80. Florez, C.; Park, Y.H.; Valles-Rosales, D.; Lara, A.; Rivera, E. Removal of Uranium from Contaminated Water by Clay Ceramics in Flow-Through Columns. Water 2017, 9, 761. [CrossRef]

81. Mullett, M.; Fornarelli, R.; Ralph, D. Nanofiltration of Mine Water: Impact of Feed pH and Membrane Charge on Resource Recovery and Water Discharge. Membranes 2014, 4, 163-180. [CrossRef] [PubMed]

82. U.S. Naval Facilities Engineering Command. Naval Facilities Engineering Service Center, Port Hueneme, Environmental Restoration \& BRAC Website. 2004. Available online: http:/ / enviro.nfesc.navy.mil/erb (accessed on 3 June 2021).

83. Dow Chemical Company. Nanofiltration for Municipal Water Treatment. 26 September 2000. Available online: http://www.dow. com/liquidseps/news/NF-Backgrounder.htm (accessed on 3 June 2021).

84. LaGrega, M.; Buckingham, P.; Evans, J. Hazardous Waste Management, 2nd ed.; McGraw-Hill Inc.: New York, NY, USA, 2000. 
85. U.S. Environmental Protection Agency. The Superfund Innovative Technology Evaluation Capsule: Filter Flow Technology Inc., Colloid Polishing Filter Method, July 1994. EPA/540/R-94/501a. Available online: https://clu-in.org/download/toolkit/540r9 4501.pdf (accessed on 3 June 2021).

86. Munter, R. Technology for the removal of radionuclides from natural water and waste management: State of the art. Proc. Estonian Acad. Sci. 2013, 62, 122. [CrossRef]

87. U.S. Environmental Protection Agency. Approaches for the Remediation of Federal Facility Sites Contaminated with Explosive or Radioactive Wastes, 1993. EPA/625/R-93/013. Available online: https://cfpub.epa.gov/si/si_public_record_report. $\mathrm{cfm}$ ?Lab=NRMRL\&direntryid=124645\&subject=homeland +security+research\&view=desc\&sortby=pubdateyear\&count=25 \&showcriteria $=1 \&$ searchall $=$ ceri\&submit $=$ search \& (accessed on 3 June 2021).

88. Benes, P.; Šebesta, F.; Sedlacek, J.; Obdržálek, M.; Sandrik, R.; Obdržálek, M. Particulate forms of radium and barium in uranium mine waste waters and receiving river waters. Water Res. 1983, 17, 619-624. [CrossRef]

89. Chellam, S.; Clifford, D.A. Physical-Chemical Treatment of Groundwater Contaminated by Leachate from Surface Disposal of Uranium Tailings. J. Environ. Eng. 2002, 128, 942-952. [CrossRef]

90. Clifford, D.; Vijjeswarapu, W.; Subramonian, S. Evaluating Various Adsorbents and Membranes for Removing Radium From Groundwater. J. Am. Water Work. Assoc. 1988, 80, 94-104. [CrossRef]

91. U.S. Environmental Protection Agency. Applications Analysis Report: E.I. DuPont De Nemours E Company/Oberlin Filter Company Microfiltration Technology, October 1991. EPA/540/A5-90/007. Available online: https://nepis.epa.gov/Exe/ZyNET. exe/10001TFD.TXT?ZyActionD=ZyDocument\&Client=EPA\&Index=1986+Thru+1990\&Docs=\&Query=\&Time=\&EndTime= $\&$ SearchMethod $=1 \&$ TocRestrict $=$ n $\&$ Toc $=\&$ TocEntry $=\& Q F i e l d=\& Q F i e l d$ Year $=\& Q F i e l d M o n t h=\& Q F i e l d D a y=\& I n t Q F i e l d O p=$ 0\&ExtQFieldOp=0\&XmlQuery=\&File=D\%3A\%5Czyfiles $\% 5 C I n d e x \% 20 D a t a \% 5$ C 86 thru90\%5CTxt $\% 5 C 00000005 \% 5 C 10001$ TFD.txt\&User $=$ ANONYMOUS\&Password $=$ anonymous \&SortMethod $=\mathrm{h} \% 7 \mathrm{C}-\&$ MaximumDocuments $=1 \&$ FuzzyDegree $=0 \&$ ImageQuality=r75g8/r75g8/x150y150g16/i425\&Display=hpfr\&DefSeekPage=x\&SearchBack=ZyActionL\&Back=ZyActionS\& BackDesc $=$ Results \%20page\&MaximumPages=1\&ZyEntry=1\&SeekPage $=x \& Z y P U R L$ (accessed on 3 June 2021).

92. Annanmaki, M.; Turtiainen, T. Treatment Techniques for Removing Natural Radionuclides from Drinking Water. Final Report of the TENAWA Project. Prepared for the Radiation and Nuclear Safety Authority of Finland (STUK), Helsinki, 2000. Report No. STUK-A169. Available online: https:/ / inis.iaea.org/collection/NCLCollectionStore/_Public/32/018/32018426.pdf (accessed on 3 June 2021).

93. Scamehorn, J.; Taylor, R.; Palmer, C. Final Report: Removal of Radioactive Cations and Anions from Polluted Water Using Ligand-Modified Colloid-Enhanced Ultrafiltration. Prepared by University of Oklahoma. Prepared for the U.S. DOE, Project No. 60041-OK. 2001. Available online: https:/ / www.osti.gov/servlets/purl/828491 (accessed on 3 June 2021).

94. Diallo, M.S. Chapter 15-Water Treatment by Dendrimer-Enhanced Filtration: Principles and Applications. In Micro and Nano Technologies, Nanotechnology Applications for Clean Water, 2nd ed.; Street, A., Sustich, R., Duncan, J., Savage, N., Eds.; William Andrew Publishing: Burlington, MA, USA, 2014; pp. 227-239, ISBN 9781455731169. [CrossRef]

95. Khedr, G. Nanofiltration and low energy reverse osmosis for rejection of radioactive isotopes and heavy metal cations from drinking water sources. Desalination Water Treat. 2009, 1944-3994. [CrossRef]

96. Montaña, M.; Camacho, A.; Serrano, I.; Devesa, R.; Matia, L.; Vallés, I. Removal of radionuclides in drinking water by membrane treatment using ultrafiltration, reverse osmosis and electrodialysis reversal. J. Environ. Radioact. 2013, 125, 86-92. [CrossRef] [PubMed]

97. Mulas, D.; Camacho, A.; Serrano, I.; Montes, S.; Devesa, R.; Duch, M.A. Natural and artificial radionuclides in sludge, sand, granular activated carbon and reverse osmosis brine from a metropolitan drinking water treatment plant. J. Environ. Radioact. 2017, 177, 233-240. [CrossRef] [PubMed]

98. U.S. Environmental Protection Agency. A Citizen's Guide to Activated Carbon Treatment, December 2001. EPA/542/F-01/020. Available online: https:/ / permanent.fdlp.gov/websites/epagov/www.epa.gov/swertio1/download/citizens/activatedcarbon. pdf (accessed on 3 June 2021).

99. Federal Remediation Technologies Roundtable. Remediation Technologies Screening Matrix and Reference Guide, Version 4.0: Adsorption/Absorption. 2002. Available online: http:/ / www.frtr.gov/matrix2/section4/4-44.html (accessed on 3 June 2021).

100. Federal Remediation Technologies Roundtable. Remediation Technologies Screening Matrix and Reference Guide, Version 4.0: Granulated Activated Carbon (GAC)/Liquid Phase Carbon Adsorption, 2002b. Available online: http://www.frtr.gov/matrix2 / section4/4-47.html (accessed on 3 June 2021).

101. Hu, J.; Lv, Y.; Cui, W.; Chen, W.; Li, S. Study on Treatment of Uranium-Containing Wastewater by Biosorption. IOP Conf. Ser. Earth Environ. Sci. 2019, 330, 032029. [CrossRef]

102. Chen, B.; Wang, J.; Kong, L.; Mai, X.; Zheng, N.; Zhong, Q.; Liang, J.; Chen, D. Adsorption of uranium from uranium mine contaminated water using phosphate rock apatite (PRA): Isotherm, kinetic and characterization studies. Colloids Surfaces $A$ Physicochem. Eng. Asp. 2017, 520, 612-621. [CrossRef]

103. Police, S.; Maity, S.; Chaudhary, D.K.; Sahu, S.K.; Kumar, A.V. An investigation on the efficiency of low-cost adsorbents in removing uranium from water samples. Appl. Water Sci. 2020, 10, 1-13. [CrossRef]

104. Yang, A.; Wang, Z.; Zhu, Y. Facile preparation and adsorption performance of low-cost MOF@cotton fibre composite for uranium removal. Sci. Rep. 2020, 10, 19271. [CrossRef] [PubMed] 
105. Su, M.; Tsang, D.; Ren, X.; Shi, Q.; Tang, J.; Zhang, H.; Kong, L.; Hou, L.; Song, G.; Chen, D. Removal of U(VI) from nuclear mining effluent by porous hydroxyapatite: Evaluation on characteristics, mechanisms and performance. Environ. Pollut. 2019, 254, 112891. [CrossRef] [PubMed]

106. Samolej, K.; Chalupnik, S. Investigations on the application of different synthetic zeolites for radium removal from water. J. Environ. Radioact. 2021, 229-230, 106529. [CrossRef]

107. U.S. Environmental Protection Agency. Treatment Technologies for Site Cleanup: Annual Status Report (Eleventh Edition), February 2004. EPA/542/R-03/009. Available online: https://www.epa.gov/sites/production/files/2015-09/documents/asr_11 thedition.pdf (accessed on 3 June 2021).

108. Federal Remediation Technologies Roundtable. Remediation Technologies Screening Matrix and Reference Guide, Version 4.0: Phytoremediation. 2002. Available online: http:/ / www.frtr.gov/matrix2/section4/4-33.html (accessed on 3 June 2021).

109. Dushenkov, S.; Vasudev, D.; Kapulnik, Y.; Gleba, D.; Fleisher, D.; Ting, K.C.; Ensley, B. Removal of Uranium from Water Using Terrestrial Plants. Environ. Sci. Technol. 1997, 31, 3468-3474. [CrossRef]

110. Han, Y.; Lee, J.; Kim, C.; Park, J.; Lee, M.; Yang, M. Uranium Rhizofiltration by Lactuca sativa, Brassica campestris L., Raphanus sativus L., Oenanthe javanica under Different Hydroponic Conditions. Minerals 2020, 11, 41. [CrossRef]

111. U.S. Environmental Protection Agency. Phytotech-Phytoextraction of Lead from Soil. 2006. Available online: http://www.epa. gov/ORD/NRMRL/lrpcd/rr/phytlead.htm (accessed on 3 June 2021).

112. Tomé, F.V.; Rodríguez, P.B.; Lozano, J. Elimination of natural uranium and 226Ra from contaminated waters by rhizofiltration using Helianthus annuus L. Sci. Total. Environ. 2008, 393, 351-357. [CrossRef]

113. U.S. Department of Energy. Subsurface Contaminants Focus Area: Technology Summary, DOE/EM-0296. August 1996. Available online: https:/ /inis.iaea.org/search/search.aspx?orig_q=RN:28005512 (accessed on 3 June 2021).

114. Wang, W.Q.; Brackhage, C.; Bäuker, E.; Dudel, E.G. Rhizofiltration of U by plant root surfaces in a tailing wetland. In UraniumPast and Future Challenges; Merkel, B., Arab, A., Eds.; Springer: Cham, Switzerland, 2015. [CrossRef]

115. Yang, M.; Jawitz, J.W.; Lee, M. Uranium and cesium accumulation in bean (Phaseolus vulgaris L. var. vulgaris) and its potential for uranium rhizofiltration. J. Environ. Radioact. 2015, 140, 42-49. [CrossRef]

116. Diamantino, C.; Carvalho, E.; Pinto, R. Water resources monitoring and mine water control in Portuguese old uranium mines. In Proceedings of the IMWA Symposium 2016, Leipzig, Germany, 11-15 July 2016.

117. Kalin, M.; Kießig, G.; Küchler, A. Ecological water treatment processes for underground uranium mine water: Progress after three years of operating a constructed wetland. In Proceedings of the Uranium Mining and Hydrogeology III Conference, Freiberg, Germany, 15-21 September 2002; pp. 591-600.

118. Rock, S. Introduction to Phytoremediation. In The Standard Handbook of Hazardous Waste Treatment and Disposal, 2nd ed.; McGrawHill Inc.: New York, NY, USA, 1997.

119. Pivetz, B. Ground Water Issue: Phytoremediation of Contaminated Soil and Ground Water at Hazardous Waste Sites. Prepared for U.S. EPA, Office of Solid Waste and Emergency Response, February 2001. EPA/540/S-01/500. Available online: https: //www.epa.gov/sites/production/files/2015-06/documents/epa_540_s01_500.pdf (accessed on 3 June 2021).

120. Waugh, W.J.; Glenn, E.P.; Benson, C.H.; Albright, W.H.; Brusseau, M.L.; Bush, R.P.; Dayvault, J. Applications of Ecological Engineering Remedies for Uranium Processing Sites, USA. 2016. Available online: https:/ /www.osti.gov/servlets/purl/1258487 (accessed on 21 April 2021).

121. Negri, M.; Hinchman, R.; Wozniak, J. Capturing a 'Mixed' Contaminant Plume: Tritium Phytoevaporation at Argonne National Laboratory East. In Proceedings of the Phytoremediation State of the Science Conference, Boston, MA, USA, 1-2 May 2000.

122. U.S. Environmental Protection Agency. Deployment of Phytotechnology in the 317/319 Area at Argonne National LaboratoryEast: Innovative Technology Evaluation Report, December 2003. EPA/540/R-05/011. Available online: https://cfpub.epa.gov/ si/si_public_record_report.cfm?Lab=NRMRL\&dirEntryId=96194 (accessed on 3 June 2021).

123. Hitchcock, D.; Rebel, K.; Barton, C.; Seaman, J.; Riha, S.; Blake, J. Estimating Efficiencies of Tritium Phytoremediation at the Savannah River Site. In Proceedings of the Annual International Conference on Soils, Sediments, and Water, Amherst, MA, USA, 22-24 October 2002. Available online: http:/ / www.umasssoils.com/posters2002/phytoremediation.htm (accessed on 3 June 2021).

124. Lewis, C.; Van Pelt, R. Natural Remediation at Savannah River Site; WSRC-MS-2002-00075; Bechtel Savannah River Inc.: North Augusta, SC, USA, 2002.

125. Schnoor, J. Phytoremediation of Soil and Groundwater; Technology Evaluation Report TE-02-01; Ground-Water Remediation Technologies Analysis Center: Pittsburgh, PA, USA, 2002.

126. Favas, P.J.; Pratas, J.; Mitra, S.; Sarkar, S.K.; Venkatachalam, P. Biogeochemistry of uranium in the soil-plant and water-plant systems in an old uranium mine. Sci. Total. Environ. 2016, 568, 350-368. [CrossRef] [PubMed]

127. International Atomic Energy Agency. Remediation of Sites with Dispersed Radioactive Contamination. Technical Reports Series No. 424; International Atomic Energy Agency: Vienna, Austria, 2004.

128. Saleh, H.M. Biological Remediation of Hazardous Pollutants Using Water Hyacinth-A Review. J. Biotech. Res. 2016, 2, 80-91. Available online: http:/ / arpgweb.com/?ic=journal\&journal=16\&info=aims (accessed on 3 June 2021).

129. Sheoran, V.; Sheoran, A.S.; Poonia, P. Factors Affecting Phytoextraction: A Review. Pedosphere 2016, 26, 148-166. [CrossRef]

130. Sellers, K. Fundamentals of Hazardous Waste Site Remediation; Lewis Publishers: Boca Raton, FL, USA, 1999. 
131. International Atomic Energy Agency. Technologies for Remediation of Radioactively Contaminated Sites; IAEA-TECDOC-1086; International Atomic Energy Agency: Vienna, Austria, 1999.

132. Adamson, D.T.; Newell, C.J. Frequently Asked Questions About Monitored Natural Attenuation in Groundwater; ESTCP Project ER-201211; Environmental Security and Technology Certification Program: Arlington, Virginia, 2014.

133. Federal Remediation Technologies Roundtable. Remediation Technologies Screening Matrix and Reference Guide, Version 4.0: Monitored Natural Attenuation. 2002. Available online: http:/ /www.frtr.gov/matrix2/section4/4-32.html (accessed on 3 June 2021).

134. Krupka, K.; Martin, W. Subsurface Contaminant Focus Area: Monitored Natural Attenuation (MNA)—Programmatic, Technical, and Regulatory Issues. Prepared for U.S. DOE by Pacific Northwest National Laboratory, July 2001. PNNL-13569. Available online: https://www.pnnl.gov/main/publications/external/technical_reports/PNNL-13569.pdf (accessed on 3 June 2021).

135. U.S. Environmental Protection Agency. EPA Superfund Explanation of Significant Differences: Teledyne Wah Chang, EPA ID: ORD050955848, OU 01, Albany, Ore., 10/08/1996, 1997. EPA/ESD/R10-97/082. Available online: https://semspub.epa.gov/ work/10/1429671.pdf (accessed on 3 June 2021).

136. U.S. Environmental Protection Agency. Fourth Five-Year Review Report for Teledyne Wah Chang Superfund Site City of Millersburg Linn County, Oregon, 28 December 2012. Contract No. 68-57-03-04 Task Order No. (011). Available online: https: / / www.deq.state.or.us/Webdocs/Controls/Output/PdfHandler.ashx?p=3c8062fe-090e-425c-af09-305c50409ba3.pdf\& s=WRDCER0315FourthFiveYearReportTeledyneWahChang01012013.pdf (accessed on 3 June 2021).

137. U.S. Environmental Protection Agency. EPA Superfund Record of Decision: Hanford 300-Area (USDOE), EPA ID: WA2890090077, OU 01, 02, Benton County, Wash., 07/17/1996, 1996. EPA/ROD/R10-96/143. Available online: https://semspub.epa.gov/work/ HQ/157870.pdf (accessed on 3 June 2021).

138. U.S. Department of Energy. Hanford Site Groundwater Monitoring Report for 2019. Revision 0. DOE/RL-2019-66. August 2020. Available online: https://www.hanford.gov/files.cfm/DOE-RL-2019-66_R0_Clean.pdf (accessed on 19 April 2021).

139. U.S. Environmental Protection Agency. Fifth Five-Year Review Report for Weldon Spring Site, September 2016, LMS/WEL/S13516. Available online: https:/ / www.lm.doe.gov/Weldon/S13516_WEL_Fifth_Five-Year_Review.pdf (accessed on 3 June 2021).

140. U.S. Department of Energy. Monticello Mill Tailings Site Operable Unit III, Annual Groundwater Report May 2015 through April 2016. October 2016. LMS/MNT/S14233. Available online: https://www.osti.gov/biblio/1349684 (accessed on 3 June 2021).

141. Bea, S.A.; Wainwright, H.; Spycher, N.; Faybishenko, B.; Hubbard, S.S.; Denham, M.E. Identifying key controls on the behavior of an acidic-U(VI) plume in the Savannah River Site using reactive transport modeling. J. Contam. Hydrol. 2013, 151, 34-54. [CrossRef] [PubMed]

142. U.S. Environmental Protection Agency. Office of Solid Waste and Emergency Response. Use of Monitored Natural Attenuation for Inorganic Contaminants in Groundwater at Superfund Sites, Directive 9283.1-36. August 2015. Available online: https: / / semspub.epa.gov/work/HQ/177087.pdf (accessed on 3 June 2021).

143. Brady, P.; Spalding, B.; Krupka, K.; Waters, R.; Zhang, P.; Borns, D.; Brady, W. Site Screening and Technical Guidance for Monitored Natural Attenuation at DOE Sites. Prepared for the U.S. DOE by Sandia National Laboratories, March, 1999. Sandia Report SAND99-0464. Available online: https:/ / www.osti.gov/servlets / purl/5651 (accessed on 3 June 2021).

144. FRTR. Contaminated Site Clean-Up Information. 2018. Available online: https:/ / clu-in.org/software/ (accessed on 3 June 2021). 